I Universidade Federal do Rio de Janeiro (UFRJ),

Programa de Pós-Graduação em Sociologia e Antropologia

(PPGSA), Rio de Janeiro, RJ, Brasil

cavalcanti.laura@gmail.com

https://orcid.org/o0oo-0002-54I5-309I

Maria Laura Viveiros de Castro Cavalcanti'

\title{
A CASA DAS MINAS DE SÃo LUÍS dO \\ MARANHÃO E A SAGA DE NÃ AGONTIMÉ ${ }^{1}$
}

A Sergio Ferretti (in memoriam)

O interesse intelectual pelas religiões afro-brasileiras ganhou forma na segunda metade do século XIX no bojo dos estudos sobre o negro e sua marcante presença na formação da sociedade brasileira. Ao longo da costa centro e sul do continente americano, descortinaram-se divindades, mitologias e práticas rituais que, muito distintas daquelas conhecidas pelo cristianismo católico então predominante, desafiavam a passagem do tempo e os forçados deslocamentos espaciais: elas haviam atravessado o Atlântico com os escravos que chegaram ao país de diferentes pontos do continente africano e também os séculos de duração do regime escravista que, no Brasil, só conheceu oficialmente seu fim em I888. Entre o final do Império e a instauração da República, as religiões afro-brasileiras revelavam-se, na linguagem antropológica contemporânea, um lugar fecundo de expressão e produção de diferenças socioculturais (Carneiro da Cunha, 1979).

Se o tráfico atlântico de escravos ligava e religava continuamente Brasil e África (Verger, I987), as crenças e práticas rituais rearticulavam-se ao chegar em novas terras, buscavam nichos secretores de sociabilidades e modos de vida próprios (Bastide, I97I) em meios sociais inóspitos. Essas duas dimensões de um mesmo processo histórico - os vínculos de Brasil e África, e a rearticulação e ressignificação de sistemas religiosos africanos em sua inserção no país emolduram o estudo das religiões afro-brasileiras. Como indicou Maggie (2015), ao longo do século XX esse estudo desdobrou-se em duas vertentes centrais: aquela que buscou africanismos e dedicou-se a remontar à origem dos rituais, 
cerimônias, cultos e objetos encontrados, em que se destacam Arthur Ramos e Melville Herskovits; e aquela que enfatizou o estudo das transformações e rearticulações das religiões ao as inserir em suas novas condições sociais, representada por autores como Robert Park, Donald Pierson, Franklin Frazier e Ruth Landes.

O animismo fetichista dos negros da Bahia, de Nina Rodrigues, publicado em I900² (ver a respeito Corrêa, I998 e Fry \& Maggie, 2006), é um marco nessa vertente caudalosa de pesquisas que integram o pensamento social e, entre r930 e I940, acompanham a configuração das ciências sociais no país. ${ }^{3}$ Esse estudo precursor compartilhava os pressupostos do racialismo e evolucionismo então vigentes, pois, ao denunciar a "ilusão da catequese", Nina Rodrigues (I935) a atribuía a uma suposta incapacidade dos negros para as "elevadas abstrações do monoteísmo". Tal perspectiva, entretanto, era muitas vezes superada pela qualidade das observações de campo relatadas. Como observou Edison Carneiro (I964: 209), Nina Rodrigues revelava em seu estudo "uma indisfarçável simpatia pelos candomblés". Merecem destaque observações lúcidas, como a que segue:

Quando em dias de abril de I895, as lutas políticas das facções partidárias deste estado chegaram a uma tensão tal que a toda hora se esperava o rompimento de uma guerra civil [...] na porta do edifício das câmaras amanhecera deposto um grande feitiço ou coisa feita. A imprensa diária meteu o caso a ridículo sem se lembrar de que era aquele um modo de intervenção da população fetichista da cidade, tão lógico e legítimo na sua manifestação sociológica, quanto era natural a intervenção do digno prelado arquidiocesano que, conferenciando com os chefes dos grupos litigantes, procurava restabelecer a paz e o amor da família baiana (Nina Rodrigues, 1935: 194).

Também em São Luís do Maranhão, a julgar pelo noticiário local, o centro religioso afro-brasileiro Casa das Minas já emergia como ativo participante da vida urbana, em data anterior àquela da situação descrita por Nina Rodrigues para Salvador, Bahia. Um pequeno anúncio no jornal A Pacotilha, de 22 de junho de 1887 , intitulado "Pedido justo", deixa entrever o preconceito existente para com a população negra:

Pede-se a pessoa que levou por brincadeira ou má intenção a imagem do Menino
Deus, da Casa das Minas, que se achava no altar ali armado, queira fazer o ob-
séquio de ir entregá-lo na referida casa, pois viu-se perfeitamente a pessoa que
tirou-a, e não se lhe disse nada para não envergonhá-lo, e não dizer-se - enfim
é festa de pretos - o que não nos doía a cabeça. Se não for entregá-lo passará
pela decepção de ver o seu nome por extenso neste jornal. Quem me avisa meu
amigo é. ${ }^{4}$

O surgimento da Casa das Minas em São Luís do Maranhão remontaria, segundo os especialistas, possivelmente às primeiras décadas do século XIX. ${ }^{5}$ Seu estudo, entretanto, só emergirá de modo mais definido nos anos I940, com os trabalhos de Nunes Pereira (I947) e Octávio da Costa Eduardo (I948). Com pesquisas iniciadas nos anos I970, e já no ambiente das pós-graduações bra- 
sileiras, Sergio Ferretti ${ }^{6}$ retomou e renovou com dois de seus principais trabalhos (Ferretti, I985 e I995)' o estudo dessa Casa "considerada a casa mãe de outros tambores de mina do Maranhão e da Amazônia, embora formalmente não haja outras que lhe sejam filiadas" (Ferreti, I985: I6). Tambor de mina é a denominação ampla dessa variante da religiosidade afro-brasileira que tem por divindades os voduns e espalhou-se por outras regiões do país.

Partindo das contribuições e indicações de Ferretti (1985, I995), este texto busca reconstituir de modo sintético os elos centrais que compuseram, de meados do século passado aos nossos dias, narrativas instigantes acerca das origens da Casa das Minas de São Luís do Maranhão. Debruça-se sobre os es tudos de Nunes Pereira (I947) e de Octávio da Costa Eduardo (I948), que, ao indicar a vinculação dos voduns nele adorados com ancestrais históricos da realeza do antigo Daomé, configuraram a singularidade desse centro religioso. Essa indicação atrairá o interesse de Pierre Verger (I953a), que formulará, por sua vez, a hipótese de que a rainha daomeana Nã Agontimé, vendida como escrava aos negreiros do tráfico atlântico entre o final do século XVIII e o início do XIX, teria fundado a Casa das Minas. Tal hipótese especulativa configura o que denominei a saga de Nã Agontimé, uma envolvente fabulação que busca preencher vazios intransponíveis, violentos traumas e silêncios seculares. Pesquisas mais recentes, ao estabelecerem dados históricos fidedignos, permitem contextualizar e relativizar a hipótese de Verger. Uma breve notícia acerca da situação atual da Casa das Minas e um modesto tributo à memória de Sergio Figueiredo Ferreti encerram nosso percurso.

\section{CASA DAS MINAS DE SÃO LUÍS DO MARANHÃO}

A Casa Grande das Minas ou Casa das Minas Jêje, situada no Centro Histórico de São Luís do Maranhão - mais precisamente na rua São Pantaleão, n. 857 está, desde 2005, entre os terreiros tombados como patrimônios culturais brasileiros pelo Instituto do Patrimônio Histórico e Artístico Nacional (Iphan). ${ }^{8}$ Assim como a Casa de Nagô, também antiga na cidade, a Casa das Minas ostenta em seu nome a marca da proveniência do grupo que a criou: eram negros minas ou minas-jêje. Mina ou Minas é termo que se refere aos escravizados vindos da região da antiga Costa do Ouro (atual Gana e mais amplamente toda a região do golfo de Benim na África Ocidental). Arthur Ramos (1947: 10) atribuiu essa denominação ao Forte de Elmina ou de São Jorge da Mina, datado do século $\mathrm{XV}$, que se tornara o principal empório de escravos da região sob os portugueses. ${ }^{9}$ Por isso, o termo teria passado a designar genericamente todos os negros embarcados daquele porto para o Brasil. Por essa razão, nos diz Ramos, na documentação do tráfico negreiro costumava-se acrescentar ao termo genérico mina, outro termo, que buscava identificar de modo mais preciso a origem étnica de um grupo: "minas-nagô; minas-gêge; minas-popô. A Casa das Minas Jêje, a que logo voltaremos em detalhe, teria sido criada por um grupo 
de africanos oriundos do antigo Daomé, atual Benim: "negros gêges, Mina-gêge" (Ramos, I947: Io). ${ }^{\text {10 }}$

No primeiro estudo de Sergio Ferretti (I985), ${ }^{\text {II }}$ a perspectiva etnográfica, com base na experiência da observação participante longa e próxima, entrelaça cuidadoso estado da arte acerca da Casa, narrativas de memória das vodunsi (as sacerdotisas ou filhas de santo que recebem as divindades, os voduns, durante o transe) sobre a história do centro religioso e suas experiências de liderança e convívio (que revelam conflitos, fofocas e disputas, diferentes perspectivas a respeito de eventos marcantes na história da Casa), o exame da organização social (a luta e negociação pelo uso e propriedade dos prédios e espaços), da mitologia (na ocasião da pesquisa mais intensiva realizada entre I974 e I978, a Casa tinha 60 divindades cultuadas), dos rituais mais íntimos e das festas religiosas que se abrem para o povo citadino em geral (as festas de são Sebastião e do Divino Espírito Santo). Ao longo de muitas décadas, o lento e progressivo declínio da Casa - do ponto de vista da ausência de renovação das iniciações plenas que garantiriam a continuidade geracional do culto ${ }^{12}-$ se ilumina à luz da singularidade de sua história associada ao culto de divindades ancestrais da realeza do antigo Daomé. Desenha-se para o leitor um ambiente quase onírico em que dados históricos se encontram com vislumbres da memória, sempre parcialmente silenciada por muitos segredos, pois, como sempre dizem as vodunsi, os voduns são discretos e não apreciam revelações.

Ferretti (I995: 217) voltaria ao tema com sua tese de doutoramento, Repensando o sincretismo: a Casa das Minas de São Luís do Maranhão, que distingue variantes do conceito de sincretismo - no final organizados pelo autor em três grupos "conforme predominam as noções de mistura, paralelismo, convergência" - que marcou a literatura pertinente. O autor reconhece a relevância de críticas ao conceito tantas vezes usado de modo simplório como uma junção quase mecânica de ideias díspares. Destaca aquela feita por Leacock e Leacock (I975) que, ao pesquisarem o batuque paraense, viram no termo sincretismo o obscurecimento do processo criativo envolvido na rearticulação de um sistema religioso. Defende, entretanto, a originalidade de seu estudo de caso que analisa "o sincretismo num dos grupos religiosos afro-brasileiros mais tradicionais" (Ferretti, I995: 222). De fato, nesse livro, que retoma aspectos do trabalho anterior, destacam-se as etnografias das festas religiosas relacionadas ao calendário ritual católico, ${ }^{13}$ que geralmente expandem as redes de relações sociais do centro religioso. São elas: a festa de Averequete (um vodum que, por sua vez, "adora" são Benedito); o banquete dos cachorros que homenageia são Lázaro; o Arrambam, que fecha os terreiros de tambor de mina no início da quaresma; a Festa do Divino Espírito Santo. ${ }^{14}$

Nesses dois livros, sempre enfatizando a contemporaneidade da Casa, Sergio Ferretti empreende também o cuidadoso registro das pesquisas anteriores. Junto à expressão de "orgulho das raízes", viu-a como uma manifestação 
da organização e criatividade populares, como uma religião em que se mesclavam "uma espécie de teatro popular, uma oportunidade de lazer, de divertimento com comidas e bebidas e encontros entre muitas pessoas - a comunidade se exterioriza" (Ferretti, I985: I5). Mais adiante reafirmou: "Privilegiamos esta casa como objeto de estudo, não com a intenção inviável de procurar africanismos puros ou de identificar núcleos religiosos mais autênticos, mas por a considerarmos como uma das mais representativas e até hoje um dos modelos de organização do tambor de mina do Maranhão" (Ferretti, I985: 50).

As narrativas acerca da história da Casa das Minas, entretanto, expressam de modo notável a força simbólica da ideia de origem nos estudos socioantropológicos das religiões afro-brasileiras. ${ }^{15}$ Trata-se de um caso em que a história do tráfico negreiro e a antropologia das religiões têm encontros bem demarcados na bibliografia disponível. A força simbólica dos mitos de origem é bem conhecida da antropologia, que entende sua narração contemporânea como a ativação de valores e significados do presente (Lévi-Strauss, I976). É mais rara, entretanto, a autoconsciência de sermos partes integrantes dos processos culturais que os fabricam. ${ }^{16} \mathrm{O}$ simples ato de recontar histórias, afinal, mesmo que para examiná-las, implica permitir que elas exerçam sobre nós sua força. Ao buscar situar os estudos de Sergio Ferretti num cenário mais amplo, ${ }^{17}$ precisei reconstruir ainda que sumariamente as narrativas existentes acerca da origem da Casa das Minas. Ao fazê-lo, surpreendi-me inteiramente absorvida por elas, que foram compondo aos poucos o desenho de um infindável quebra-cabeças. Em torno da Casa das Minas, como veremos, mito e história entranharam-se em um caso único, cujo estudo continuará por muito tempo a atrair futuros pesquisadores no Brasil e mundo afora.

\section{A CASA DAS MINAS E O DAOMÉ. OS ESTUDOS DOS ANOS 1940}

Os estudos afro-religiosos no Maranhão ganharam forma definida na segunda metade dos anos I940. ${ }^{18}$ Em I947, Nunes Pereira (I947) publicou a monografia A Casa das Minas. Contribuição ao estudo das sobrevivências daomeianas no Brasil. ${ }^{19}$ No ano seguinte, Octávio da Costa Eduardo (1948) publicou The negro in Northern Brasil. A study in acculturation (ver Ferretti, 20I7). Esses dois estudos trazem consigo a marcante presença dos dois expoentes mundiais dos estudos afro-brasileiros e afro-americanos da época - Arthur Ramos e Melville Herskovits, respectivamente. Sua publicação em datas tão próximas é, por si, significativa.

Arthur Ramos introduz o texto de Nunes Pereira, autenticado pela experiência vivida e qualificado pelo próprio autor como um depoimento, oriundo do convívio religioso cotidiano datado da infância, pois sua mãe e sua madrinha teriam sido vodunsis da Casa das Minas. Melville Herskovits orientou, por sua vez, Octávio da Costa Eduardo em seus estudos pós-graduados na Northwestern University, nos Estados Unidos. ${ }^{\circ} \mathrm{O}$ livro de Nunes Pereira inaugura as publicações da Sociedade Brasileira de Antropologia e Etnologia que, fundada por Ar- 
thur Ramos, se encerrou com sua morte em I 949. ${ }^{2 \mathrm{I}}$ O livro de Octávio da Costa Eduardo, por sua vez, é o I $5^{\circ}$ número da série de monografias da American Ethnological Society. A influência intelectual de Herskovits sobre Ramos é bem conhecida, e eles mantiveram estreito relacionamento, tendo mesmo planejado, por ocasião do seminário Aculturação, realizado na Northwestern University em I94I (Ramos, I947), uma viagem conjunta de estudos ao Maranhão, da qual se encarregaria Octávio da Costa Eduardo por sugestão de Herskovits. Os esperados resultados da pesquisa de Eduardo ainda não estavam disponíveis quando Ramos escreveu sua introdução ao livro de Nunes Pereira.

O conceito de aculturação - que enfatiza o exame de traços culturais remanescentes de uma cultura originária ${ }^{22}$ - e mesmo aquele de transplantação - uma metáfora botânica - compõem o pano de fundo dos trabalhos de Nunes Pereira e de Eduardo. A busca das origens, em suma, predominante no enfoque socioantropológico das religiões no país até os anos I970 (Maggie, 20I5), inspira esses estudos, bem diferentes, entretanto, em sua natureza.

Nunes Pereira, cujo relato é dedicado a Andresa Maria, então a principal vodunsi da Casa, é apresentado por Ramos como um "ilustre etnógrafo amazonense". Mãe Andresa, segundo Ferretti (I985), teria assumido o comando da casa de I9I4 a I954 e foi sua última grande chefe, pois o ritual que completaria o processo de iniciação de novas gonjaí, ${ }^{23}$ de modo a incorporar novas gerações à possibilidade de expressão religiosa plena, nunca foi promovido por ela. Mãe Andresa era a guardiã de preciosa memória, a qual, registrada por Nunes Pereira (I947) e por Eduardo (I948), logo atrairá a atenção de Pierre Verger (I953a), ${ }^{24}$ em cujas formulações se imbricarão, já na segunda metade do século XX, o interesse religioso e por pesquisas documentais sobre o tráfico atlântico.

Para Nunes Pereira (I947: I8-I9): "A Casa é das Minas, sim, de uma sociedade africana transplantada para o Brasil, mas o patrimônio que ela representa está confiado a uma verdadeira Mãe: autoritária, quando é mister; boníssima, sempre". A Casa chama-se Querebetan em língua jêje, e, "se o tipo da Casa, na sua arquitetura, é colonial portuguesa, a sua alma é lidimamente africana, como a de Mãe Andresa Maria" (Nunes Pereira, I947: 23): "Ali, há mais de um século, alguns Negros Minas se constituíram em sociedade genuinamente africana, com as suas leis, os seus deuses, os seus costumes e as suas tradições" (Nunes Pereira, I947: I9). Ele queria saber da "fundação dessa Casa, isto é, do ato social, político, religioso tradicional que a estabeleceu lá na antiga São Pantaleão!" (Nunes Pereira, I947: 22, itálico do autor). A resposta lhe chegou pela oralidade: "A Tradição, falando através da boca de Andresa Maria, diz que quem a 'assentou' foi contrabando". E, segundo Almerinda, sua madrinha, era "gente vinda diretamente da África, Mina-Gêge. Trouxeram o pegi das divindades cultuadas consigo". ${ }^{25}$ "Nós é que estamos zelando" (Nunes Pereira, I947: 22), afirma sempre a dona da Casa. 
Na opinião de Arthur Ramos (I947), a pesquisa pioneira de Nunes Pereira supria uma importante lacuna na série dos estudos brasileiros sobre o problema do negro. Ao comentá-la, Ramos configura com clareza os contornos do que viria a caracterizar, de modo cada vez mais nítido na literatura subsequente, a singularidade da Casa das Minas de São Luís do Maranhão em meio à história das religiões afro-brasileiras. Segundo Ramos, Nina Rodrigues já teria registrado fragmentos culturais deixados pelos "geges ou Ewes, mas tão íntima foi sua fusão com os Nagôs, predominantes em número, que a Mítica gêge foi quase totalmente assimilada pela mítica yoruba correspondente, a ponto de se falar, desde os tempos das primeiras pesquisas, numa religião ou mitologia 'gêge-nagô', com referência ao conjunto de traços estudados" (Ramos, I947: 5-6). As evidências de tradições e divindades jêjes até então existentes constituiriam apenas traços isolados, vestígios. ${ }^{26}$ No Maranhão, entretanto, essas tradições existiriam como um verdadeiro "bloco cultural": "Lá existe, de forma institucionalizada, o culto dos voduns, onde a filiação daomeiana pode ser facilmente identificada" (Ramos, I947: 8). ${ }^{27}$

Esse "rico filão de sobrevivências africanas no norte do Brasil" (Ramos, I947: 9) demonstrado por Nunes Pereira terá seus contornos reforçados e enriquecidos por novos dados com a pesquisa de Octávio da Costa Eduardo (I948: I I), que enfoca, justamente, o "problema geral das sobrevivências africanas entre os negros do Norte do Brasil". ${ }^{28}$ A densa pesquisa compara comunidades rurais e urbanas maranhenses em termos da presença de padrões africanos de organização econômica, familiar e religiosa, e empreende um exaustivo trabalho de análise de dados populacionais e de inventários dos escravos no Maranhão. ${ }^{29}$ Nesse estudo desenha-se com clareza a singularidade do dito grupo negro de ascendência daomeana assinalada por Nunes Pereira. Vale citar um trecho mais longo:

Se invertermos nossa ênfase e tentarmos descobrir a data de chegada mais antiga para uma ou ambas as tribos [povos iorubanos e daomeanos], encontramos certos fatos relativos ao grupo de ascendência daomeana que devem ser mencionados aqui. Como será visto mais adiante esse grupo está familiarizado com o nome do rei daomeano Agongolo ou Agongoro, que governou Daomé de 1789 a I797, segundo Le Herissé, e de I789 a I8I8, segundo Burton e Skertchly..$^{30}$ Esse nome, ligeiramente modificado para Agongono, com tônica na penúltima sílaba, em vez de na antepenúltima, como pronunciado no Daomé, é dado também a uma das divindades cultuadas pelo grupo e pode ser tomado como indício de que os escravos daomeanos chegaram ao Maranhão no final do século XVIII ou início do século XIX. Isso não significa que escravos daomeanos não foram trazidos mais tarde, mas é bastante intrigante descobrir que o nome do grande rei Ghézo, que reinou de I818 a I858, é totalmente desconhecido para essas pessoas. Isso sugere que a proporção de escravos introduzidos antes de I8I8 foi maior do que a introduzida depois. Nesse contexto, podemos notar que a maioria dos escravos mina foi mencionada nos inventários para o ano de I8I5 [...] Se dados posteriores confirmarem o que esses materiais indicam, pode-se dizer que o grupo daomeano manteve sua identidade no Maranhão durante mais de I50 anos (Eduardo, I948: I4-I5). 
$\mathrm{Na}$ visão do próprio Arthur Ramos, ${ }^{3 \mathrm{I}}$ a hipótese atestada pela monografia de Nunes Pereira de proveniência africana direta da Casa das Minas era ainda especulativa, pois derivava do critério de comparação cultural de traços minas-jêje encontrados tanto no culto dos voduns da Casa das Minas em São Luís como no culto daomeano. Com o trabalho de Octávio da Costa Eduardo, contudo, a hipótese ganha nova densidade e aproxima-se do fato histórico, pois a análise de inventários regionais atesta a presença relevante de grupos de escravos daomeanos que teriam chegado ao Maranhão em torno de I8I5. Eduardo (I948) aproxima o padrão dos agrupamentos de divindades de culto em famílias, bem como a mitologia da Casa das Minas, daqueles existentes no culto aos voduns no Daomé. ${ }^{32} \mathrm{Em}$ especial, os nomes das divindades cultuadas no Maranhão seriam, informa Eduardo (I948: 77), "impressionantemente semelhantes, quando não idênticos àqueles dos reis do Daomé”. ${ }^{33}$ Ele prossegue com um comentário tão notável quanto sua descoberta:

O grupo daomeano do Maranhão não sabe que essas divindades têm os nomes dos reis daomeanos, mas é difícil acreditar que isso não era do conhecimento de seus antepassados [...] O fato de que os nomes dos reis daomeanos são dados a divindades adoradas pelo grupo daomeano é prova suficiente de que a adoração dessas figuras reais daomeanas prossegue hoje por esse grupo no Brasil, ainda que sem saber.

A relevância etnográfica dos trabalhos de Nunes Pereira (I947) e de Eduardo (I948) ressoará na segunda metade do século XX. A hipótese da conexão da Casa das Minas com a realeza daomeana ecoará além do campo das ciências sociais ou dos estudos religiosos, imprimirá sua marca no imaginário intelectual da época e ganhará a atenção de historiadores do tráfico atlântico de escravos. Nesse cenário, Pierre Verger emerge como um autor/ator central na construção de uma narrativa-síntese acerca da origem da Casa das Minas.

Como bem sintetizou Ferretti (I985: 25), sendo a Casa das Minas uma das mais antigas casas de culto afro-brasileiras que sobrevivem até hoje e talvez "o único lugar fora da África em que são cultuados voduns da família real de Abomey", Pierre Verger (I953a) apresentou a hipótese de que a Casa das Minas teria sido fundada por membros da família real de Abomé, entre eles a rainha Agontimé, vendidos como escravos para o Brasil no reinado de Adandozan (ou Adanzan) (I797-I8I8). Pierre Verger colorirá - com nomes, dados e detalhes históricos - o laço até então suposto a ligar a Casa das Minas maranhense à antiga realeza do Daomé.

Abomé, localizada no interior do território africano, é a capital histórica do antigo reino do Daomé, que existiu entre I645 e I900, até sua tomada final em I 904 pelos franceses, com o que se iniciou o período colonial da história do Daomé. ${ }^{34} \mathrm{O}$ período histórico abarcado pela hipótese de Verger abrange os reinados de Agongono entre I789 e I797, aquele de Adandozan entre I797 e I8I8, e o de Ghézo entre I8I8 e I858. 


\section{AS HIPÓTESES DE PIERRE VERGER E SEUS DESDOBRAMENTOS}

Em I953, o diretor do Institut Français de l'Afrique Noire (Ifan), Théodore Monod, agradece os esforços de Pierre Verger, colaborador do Ifan desde I940, para a publicação do número 27 da série Mémoires de L'Institut Français d'Afrique Noire, intitulado Les afro-américains, dedicado a compreender as relações entre os negros dos dois lados do Atlântico. O esforço vinha se somar àquele da Unesco, que conduzia naquele mesmo momento ampla pesquisa sobre a experiência brasileira de relações entre negros e brancos e os resultados de um contato social que ignoraria "as temíveis e ameaçadoras tensões que se pode observar alhures" (Monod, I953: 7). ${ }^{35}$ É expressiva a participação do caso brasileiro no número, enfocado tanto no item África - com o dossiê de quase roo páginas de Pierre Verger (I953b) sobre a "Influência do Brasil no Golfo de Benim" ${ }^{6}$ - como com uma seção sobre o Brasil que reúne artigos de boa parte dos principais especialistas da época: Roger Bastide, Edison Carneiro, Octávio da Costa Eduardo, Gonçalves Fernandes, Gilberto Freyre, Joseph H. Greenberg, Carlos Ott, Donald Pierson e Pierre Verger, este último com o segundo artigo de sua autoria no volume (Verger, I953a) ${ }^{37}$ para o qual nos voltamos. ${ }^{8}$

Nesse artigo, Pierre Verger ${ }^{39}$ apresentou a hipótese de que o culto dos voduns de Abomé teria sido trazido para São Luís do Maranhão no começo do século XIX pela mãe do rei Ghézo, vendida como escrava ao tráfico negreiro pelo irmão por parte de pai de Ghézo, o rei Adandozan. Desde há muito a realeza daomeana vendia, para os portugueses, escravos de grupos inimigos capturados em guerras. Verger (I953a: I58), entretanto, informa que nenhum rei de Abomé jamais vendera como escravo um daomeano de Abomé: "Eles entregavam seus inimigos aos negreiros mas, assim como a terra do reino, nenhum abomeano podia ser alienado".40 Quando da morte do rei Agongono, contudo, Adandozan, seu filho mais velho, ao assumir o reino em I797, teria se celebrizado por atos violentos e cruéis, entre eles a venda de membros da família real para os negreiros. Essa parte deportada da família estaria relacionada a seu irmão por parte de pai, Ghézo, que, por sua vez, em I8 8 tomaria o trono a Adandozan. Durante seu reinado, que perdura até I 858 , Ghézo teria enviado embaixadores em busca do paradeiro de sua mãe nas Américas.

Desejos misturados a dados oriundos das duas margens do Atlântico confluem para a construção da hipótese. Há, na margem brasileira, o desejo de Verger de explicar a intrigante presença de divindades da família real do Daomé no culto da Casa das Minas do Maranhão. Na margem africana, transparece nas fontes utilizadas o desejo de engrandecimento da memória do "grande rei Ghézo" (Eduardo, I948: I5) na história da realeza do antigo Daomé. ${ }^{41} \mathrm{~A}$ hipótese, cuja construção somos convidados a acompanhar, interpela de imediato o leitor não apenas pelos vívidos detalhes provenientes de pesquisa e da longa vivência de Verger na África. Subjaz a seu texto um notável pathos dramático, pois os passos da história narrada encarnam-se em ações de sujeitos 
comprovada ou supostamente históricos. As informações até então existentes relativas às conexões dos voduns maranhenses com os da família real do Daomé, expandidas por dados convergentes, articulam-se em uma narrativa que, ainda que apresentada como pura especulação, ganha de imediato grande eficácia simbólica.

Resumo a leitura trazida por Verger (1953a) das cinco fontes das quais se extraem os detalhes que comporão sua própria versão final. Entendo-as como variantes míticas de uma mesma história que passo a denominar a saga de Nã Agontimé. Ao mesmo tempo, procuro contextualizar tais fontes ainda que brevemente.

Fonte I: Auguste Le Hérissé foi administrador colonial no Daomé, ${ }^{42}$ tendo se casado com uma princesa da família real. Era membro correspondente do Comité d'études historiques et scientifique de l'Afrique Occidentale Française, e seu livro - L'Ancien royaume du Dahomey. Moeurs, réligion, histoire (Hérissé, 20I4), publicado originalmente em I9 I - é considerado um valioso relato acerca do antigo reino. Tal como composta por Verger, essa versão narrativa destaca a rivalidade existente entre Adandozan e Ghézo que emerge do testemunho de um chefe nativo a Le Hérissé. Ghézo, ainda menor por ocasião da morte de seu pai, é quem teria sido indicado pelo oráculo de Ifá como seu digno sucessor. Adandozan "era filho de uma outra mulher de Agonglo", e Ghézo o teria derrubado do trono em I8I8, pois "suas atrocidades e injustiças haviam atormentado os daomeanos", entre elas: "Adandozan não havia hesitado em vender aos mercadores de escravos da costa a mãe de Ghézo e uma parte de sua família" (Verger, I953a: I57).

Fonte 2: Le pacte de sang au Dahomey, de Paul Hazoumé (I937). Hazoumé nasceu no Benim e celebrizou-se como intelectual e escritor africano francófono.43 O livro foi publicado pelo Instituto de Etnologia da Universidade de Paris. O nome da mãe de Ghézo, Nã Agontimé - procurada sem sucesso por embaixadores reais daomeanos no Brasil e nas Antilhas -, é trazido por essa fonte. O livro de Hazoumé examina o valor e a extensão da instituição do pacto de sangue no antigo Daomé: uma relação ritual profunda que, sobreposta à lealdade com os parentes, ligava os pactuantes por meio da obrigação de ajuda mútua por toda a vida, com solidariedade, confiança ilimitada e grande discrição. O relato acerca da kpojito Agontimé - que interessa a Verger - emerge já no primeiro capítulo, em que Hazoumé define a etimologia da palavra Kpojito [kpo (o leopardo) + dji (dar à luz, parir) + to (a pessoa, ou pai, que pariu o leopardo]: "Era o tratamento consagrado às mães dos reis pois supunha-se que o rei era um leopardo, descendente de Agassou, o ancestral da família real. Agontimé era o nome da mãe de Ghézo" (Hazoumé, I937: 6, nota I). A menção ao "sacrilégio" da venda de Agontimé emerge no contexto do exame empreendido por Hazoumé de um dos mais célebres pactos de sangue do reino do Daomé: aquele firmado entre o mercador de escravos Francisco Félix de Souza, o chachá de 
Ajudá, ${ }^{44}$ e o príncipe Gapê. Graças ao apoio que lhe teria dado Francisco Félix, Gapê ascende ao poder e, já como rei Ghézo, deseja "reencontrar sua mãe, a rainha Agontimé, vendida aos negreiros por Adandozan" (Hazoumé, I937: 31).45

Fonte 3: O livro Daomé, de Cortez Curado (I888), major do Exército português que comandou o forte e o distrito de Uidá entre I 885 e I $887 .{ }^{46} \mathrm{Com}$ base nessa fonte emerge nomeado um dos embaixadores enviados por Ghézo às Américas. Chamava-se Dossouyévo (também Dossou-Yovo) ${ }^{47}$ e fora dignatário da corte do rei Agongono (o pai de Adandozan e de Ghézo); falante do português e do inglês, era homem de confiança do mercador Francisco Félix. Curado teria encontrado pessoalmente Dossouyévo no Daomé já na velhice. Ele se lembraria, entretanto, apenas de sua participação na embaixada enviada por Ghézo a dom João VI em I8I8, que teria ficado retida na Bahia durante três anos sem alcançar a corte. A viagem de Dossouyévo teria nesse caso outro motivo que não a busca de Nã Agontimé. 48

Fonte 4: O Livro de família de Oliveira, natural de Uidá, viria, entretanto, confirmar a versão da busca de Agontimé pelas Américas, com uma variação: os embaixadores não teriam buscado a mãe biológica de Ghézo, pois "Foi sua mãe de criação (Ghézo perdera sua verdadeira mãe poucos dias depois de seu nascimento) quem foi deportada além-mar por Adandozan. Ele [Ghézo] implorou a Francisco Félix de Souza - o grande mercador de escravos de Ajudá, aliado de Ghézo - para que a reencontrasse custasse o que custasse" (Verger, I953a: I58).

Fonte 5: O relato de um neto de Dossouyévo a Verger vem confirmar o pedido do rei Ghézo a Francisco Félix de Souza e a seu avô, dignatário da corte do rei Agongono, que teria tido relevante participação na derrubada de Adandozan. É dele a fala transcrita por Verger (I953a: I58): "Foi mesmo Nã Agontimé ela mesma que foi reencontrada por meu avô. Mas foi em Cuba que os enviados daomeanos esperaram três anos até encontrarem uma passagem para o Brasil e quando eles reencontraram a mãe de Ghézo, eles praticamente não tinham mais dinheiro. Dossouyévo deixou Atindé Bakou [também Atindebacou, o outro embaixador daomeano enviado por Ghézo] e retornou ao Daomé; Ghézo lhe deu três barras de ouro; ele partiu novamente e três meses depois ele voltou com a rainha-mãe". 49

Aspectos dessas diferentes versões narrativas se fundem na composição da hipótese final de Verger (I953a: I58): a mãe de Ghézo estaria entre os membros da família do rei Agongono que "foram vendidos depois de sua morte como escravos e transportados para um ponto desconhecido das duas Américas". Teriam chegado ao Maranhão, o único lugar das Américas onde divindades ancestrais da família real de Abomé são cultuadas. Os nomes de voduns de uma família em especial dessas divindades, a ele citados em I 948 por mãe Andresa em São Luís do Maranhão, teriam sido imediatamente reconhecidos 
pelo principal sacerdote de Abomé como correspondendo àqueles dos antigos reis do Daomé. ${ }^{\circ}$ Como nenhum vodun da lista apresentada por Andresa é posterior ao rei Agongono, fato, aliás, já assinalado por Eduardo (I948), Verger (I953a: I60) conclui: "Seria bem possível que o culto das divindades dos reis de Abomé tenha sido estabelecido na 'Casa das Minas' de São Luís do Maranhão por Nã Agontimé, viúva do rei Agongono, mãe de Ghézo que, com uma parte de sua família, foi enviada como escrava por Adandozan e que Dossouyévo e Migan Atindebacou procuraram por tanto tempo em fazendas das duas Américas".

A romancista norte-americana Judith Gleason (1970) atendeu ao apelo de Verger à imaginação investigativa de seus leitores. Essa pletora de elementos transformou-se no romance Agõtime: her legend. Gleason pesquisou no Maranhão e na Bahia, seus capítulos são ilustrados por Carybé, e Verger, que ela nomeia apenas como Fatumbi, ${ }^{51}$ foi um de seus principais interlocutores entre os estudiosos do tema: "Era uma vez uma rainha negra, Agontimé, exilada pelo destino de uma África real. Os deuses que ela trouxe para o Novo Mundo conheceram uma modesta sobrevivência. Esta é a sua história, uma exploração de seu destino não louvado" (Gleason, I970: V).

Sob inspiração direta da monografia de Nunes Pereira, o caminho da Casa das Minas da vida real para a ficção literária também ressoou nacionalmente com o romance Os tambores de São Luís, do intelectual maranhense Josué Montello (I975). Montello compartilhava com Nunes Pereira o sentimento de proximidade da Casa das Minas pelo viés afetivo da vivência de infância em São Luís. ${ }^{52}$ Os tambores da Casa abrem o romance e ressoam pelas ruas por onde trafega Damião, seu principal personagem: instado pelas mãos de Nochê Andresa Maria, Damião adentra a Casa da rua de são Pantaleão, onde "como que se reintegrava no mundo mágico de sua progênie africana [...] qual se voltasse a lhe ser propício o vodum que acompanha na Terra os passos de cada negro". Era então "outra vez o negro puro, filho de sua raça, em contato com as remotas raízes africanas" (Montello, I975: 7).

As pesquisas de Verger sobre as relações Brasil/África culminaram na publicação da edição francesa em I968 de Fluxo e refluxo (Verger, I987). Como corroboram Soares (20I4) e Parés (20I3), Verger localizou e transcreveu no capítulo VII do livro, nove cartas dos monarcas daomeanos Agongono e Adandozan aos monarcas portugueses. Um ano antes, em I967 (Soares, 2014), uma visita ao Museu Nacional, no Rio de Janeiro, lhe trouxera o conhecimento da coleção de objetos daomeanos que então compunha o acervo museológico da instituição. ${ }^{53}$ No artigo "Uma rainha africana mãe de santo em São Luís" (Verger, I990), ${ }^{54}$ ao qual logo voltaremos, tais objetos comporão um desdobramento da hipótese inicial da fundação da Casa das Minas por Nã Agotimé.

No intervalo entre a ida de Verger ao Museu Nacional, em I967, e seu artigo de I990, nos dias 24 a 28 de junho de I985, a Unesco promoveu junta- 
mente com a Universidade Federal do Maranhão o colóquio "As sobrevivências das tradições religiosas africanas nas Caraíbas e na América Latina". Diversos centros de pesquisas nacionais e internacionais estiveram presentes, e estudiosos de países africanos, Cuba, Haiti, Venezuela, Caraíbas e Brasil (Rio de Janeiro, Maranhão, Bahia, São Paulo) apresentaram trabalhos e redigiram um relatório final (Unesco, I986). O diretor-geral da Unesco foi representado pelo diretor da Divisão dos Estudos e Difusão Cultural, Maurice Glélé, e vale a pena saber que Glélé, do Benim, é um descendente direto do rei Ghézo (Costa e Silva, 2004: 87). ${ }^{55}$ Sergio Figueiredo Ferretti (1986) presidiu os trabalhos e apresentou a comunicação "As religiões de origem africana no Maranhão", um panorama geral da religiosidade afro-brasileira no Maranhão. Pierre Verger (I986a, I986b) apresentou "As contribuições especiais das mulheres do candomblé no Brasil" e "Um estudo sobre as divindades iorubas, fon, banto com os lugares de culto no Brasil e em paralelo os nomes das divindades correspondentes em África e sua localização" que, malgrado o título, aborda apenas as divindades iorubas. São três atores-chave cujo encontro no colóquio talvez ajude a entender por que, muito embora a Casa das Minas não figure de modo especial nos trabalhos apresentados, o relatório final atesta: "São Luís e a experiência original da Casa das Minas, fundada no Brasil pela Rainha Agontimé, mãe do rei Ghézo, condenada à deportação a seguir a um ajuste de contas no seio da família real, antes que o seu filho acedesse ao trono do Daomé em I8I8 e lançasse uma vasta operação em busca da mãe [...] [Na comunidade da Casa das Minas] as sujeições rituais decorrentes da sua origem fon não excluem de maneira alguma as exigências de integração profunda no contexto sociocultural e político-econômico brasileiro" (Unesco, I986: 34).

A hipótese especulativa formulada por Verger em I953 emerge como afirmação no relatório da Unesco de I986. Quatro anos depois, Verger retoma parte dos argumentos já apresentados e busca complementá-los com o conhecimento, obtido em I967, da coleção dos objetos daomeanos do Museu Nacional: "Parece que houve represálias ao bárbaro tratamento infligido por Adandozan a Nã Agontimé, mãe de Ghézo. O trono de Adandozan não figura no Museu Histórico de Abomé. Pode-se pensar que, por espírito de retaliação, este trono de Adandozan teria sido mandado por Ghézo em exílio no mesmo Brasil onde Nã Angotimé foi vendida" (Verger, I990: I54). É bem verdade que Verger se refere também à hipótese alternativa de que tais objetos tivessem sido enviados pela embaixada do rei Adandozan ao rei de Portugal em I8Io. Ele reitera, contudo, a primeira hipótese, que viria reforçar aquela anterior da fundação da Casa das Minas por Nã Agontimé como uma possível comprovação: o trono encontrado no Museu Nacional atestaria a retaliação de Ghézo à deportação de sua mãe por Adandozan. ${ }^{56}$ Origem, identificação e data de envio dos objetos da coleção daomeana foram, entretanto, bem estabelecidas tanto pela museologia e pesquisa de acervo do Museu Nacional (Soares, 20I4) como pela publicação 
de todo o conjunto das cartas daomeanas enviadas aos reis de Portugal (Parés, 2013).57 Em I990, Verger não conhecia a carta do rei Adandozan a dom João V, datada de 9 de outubro de I8Io - a carta I3 publicada por Parés (2013) -, na qual se encontram nomeados um a um os objetos que viriam a integrar - por caminhos também já deslindados - a coleção daomeana do Museu Nacional (Soares, 20I4). A hipótese de que o trono daomeano existente na coleção brasileira resultaria de retaliação por parte de Ghézo não encontrou bases plausíveis. A saga de Nã Agontimé, entretanto, cala mais fundo no imaginário intelectual.

\section{A SAGA DE NÃ AGONTIMÉ}

Os personagens históricos centrais das narrativas que compõem a saga se entrelaçam por fortes liames de parentesco: Adandozan e Ghézo são classificados como irmãos por parte de pai, o rei Angongono; e Nã Agontimé, vendida aos negreiros por Adandozan, nos é apresentada como a mãe de Ghézo, que teria mandado buscá-la nas Américas, onde ela teria, possivelmente, fundado a Casa das Minas de São Luís do Maranhão. Os sistemas de parentesco, entretanto, variam enormemente entre as diferentes sociedades humanas, abarcam laços consanguíneos, laços de afinidade e laços rituais e políticos que se articulam em complexos padrões de comportamento, obrigações morais e em diversas terminologias classificatórias. No antigo Daomé, religião, poder e parentesco associavam-se intimamente. Pesquisas acadêmicas mais recentes acerca da história do Daomé e do tráfico negreiro atlântico lançam nova luz sobre os personagens da saga e permitem melhor dimensionar as ações a eles atribuídas nas narrativas apresentadas. Para tanto, retomo, e de certo modo reconto, a saga de Nã Agontimé, contextualizada e relativizada pelas leituras que pude empreender acerca do tráfico atlântico que então ligava o Brasil/Portugal ao Daomé. Utilizo como referências os trabalhos de Soares (20I4), Parés (20I3), Costa e Silva (I 998, 2004) e Bay (I995, I998)..$^{8}$

Entre o final do século XVIII e as primeiras décadas do XIX, como indicou Parés (20I3), transformações profundas no mundo atlântico entrelaçaram o Daomé e a Costa da Mina, a Europa e o Brasil (ver também Costa e Silva, I994). Napoleão guerreava na Europa e, em i 808, a família real portuguesa deslocava-se para o Brasil; os principais portos africanos do tráfico passavam por acirradas disputas e se reordenavam na Costa da Mina. Enquanto a Inglaterra declarava o final do tráfico em I807, "crescia a demanda por escravos no Brasil em decorrência de um novo surto de prosperidade no setor açucareiro provocado pela saída de cena do Haiti" (Parés, 2013: 300). Se o tráfico negreiro para as colônias britânicas e os Estados Unidos estava proibido, e acarretara a queda do preço dos cativos em Ajudá "a um pouco menos da metade dos níveis anteriores a I807", nos portos brasileiros, na mesma época, o preço dos escravos "subira de forma considerável" (Costa e Silva, 2004: 8I). Assim é que, mesmo depois da assinatura do Tratado de Aliança e Amizade com a Inglaterra (I8Io), que previa 
a abolição do tráfico de escravos africanos pelos portugueses, o tráfico do golfo de Benim para o Brasil permaneceu intenso (Soares, 20I4), e o embarque de escravos pelos portugueses era mesmo, segundo Costa e Silva (2004), autorizado a partir de Ajudá, embora não em outros portos da costa. ${ }^{59}$

Na primeira metade do século XVIII, os daomeanos percebiam-se como guerreiros e não como mercadores de escravos, pois apenas depois de reservar para sacrifícios partes significativas dos prisioneiros de suas guerras, colocavam os demais no mercado do tráfico (Costa e Silva, 2004). Os sacrifícios humanos, por sua vez, eram parte da permanente comunicação simbólica estabelecida entre a realeza e seus ancestrais tornados divindades: os humanos sacrificados eram considerados mensageiros entre os vivos e os habitantes do reino das sombras ou mesmo seus acompanhantes e cuidadores, que deveriam continuar a zelar por eles (Bay, I995). Costa e Silva (I994: 24-25) comenta o quanto a ideia de Estado-nação no Daomé desdobrava-se "sob o disfarce de eternidade" como uma realidade espiritual: "dela e de sua representação como estado não se excluíam os ancestrais e os vindouros".

No final do século XVIII, Adandozan já era o grande fornecedor de escravos da região. No mesmo período, Francisco Félix de Souza - um ator central nos bastidores da saga de Agontimé - já era também nitidamente reconhecido pelos daomeanos como comandante do forte de Ajudá (Costa e Silva, 2004). Ajudá era então uma cidade "grande e espalhada", "distante quase cinco quilômetros da praia" e uma larga estrada real - com hospedarias vigiadas pelos espiões reais, centros religiosos e mercados - ligava-a a Abomé, a capital do reino. Francisco Félix atuava como uma espécie de agente comercial nas articulações do tráfico, adiantava mercadorias ao rei contra a entrega de cativos. Certa feita, não tendo a troca sido cumprida, Francisco Félix, indo queixar-se a Adandozan, terminara preso. Teria sido nessa ocasião, nos diz Costa e Silva (2004) conforme Hazoumé (I 937), que o príncipe Gapê o teria visitado na prisão e firmado com ele o compromisso de lealdade inquebrantável e fidelidade absoluta do pacto de sangue. O mercador se tornaria um dos articuladores centrais na ascensão de Gapê ao poder como rei Guézo, e as sagas de família contam que Guézo concedeu a Francisco Félix não só terras como o monopólio da exportação de escravos (Costa e Silva, 2004). De sua parte, Francisco teria sido um competente agente do rei e "soube aproveitar a expansão da demanda no Brasil e, a partir de I820, o consequente aumento dos preços de exportação no litoral africano, para devolver a Ajudá a condição de grande centro do comércio de escravos: já agora, o segundo ao norte do Equador, logo depois de Lagos" (Costa e Silva, 2004: 90). Essa posição africana e as relações mantidas por Francisco Félix no outro lado do oceano com importadores de escravos, donos de navio e financiadores do tráfico o teriam qualificado perante Guézo "também como mediador dos esforços de encontrar, resgatar e trazer de volta aquela que deveria ser sua kpojito, sua rainha-mãe" (Costa e Silva, 2004: I03), embarcada como escrava por Adandozan. 
A ascensão de Adandozan ao trono, em I797, ocorrera de forma ainda mais violenta que a de outros reis do Daomé (Costa e Silva, 2004), em meio a acirradas disputas entre um príncipe tido como irmão de Angongono e outros dois filhos seus - Dogan e Anibabel. ${ }^{60}$ Os reis tinham haréns, e Bay (I995) narra detalhes das diversas conspirações sucessórias em que as mulheres de origem comum, esposas do rei, em especial as candidatas ao posto de rainha-mãe, tinham papel ativo. O derramamento de sangue de membros da estirpe real era tabu, e as formas de eliminação dos adversários indesejados e politicamente perigosos abrangiam torturas cruéis, abandono ao mar, afogamento e sua venda como escravos às Américas: "E foi este o destino de muitos - cerca de seiscentos dos partidários de Dogan e Anibabel" (Costa e Silva, 2004: 83). Entre eles, a futura kpojito, Nã Agontimé.

A escolha feita por Ghézo dessa esposa de Agonglo como rainha-mãe associa-se claramente a sua ascensão ao poder em I8I8. Embora Bay (I995: I9) mencione que, por volta de I840, "uma pessoa foi instituída para reinar como kpojito, sob o nome de Agontimé", nenhum dos relatos a que tive acesso indica quando exatamente essa eleição teria ocorrido, e as razões dessa escolha permanecem especulativas.

Kpojito Agontimé, nomeou-a Hazoumé (I937). Nã Agontimé, nominou-a Verger (I990). Na, Nã, Naye, Naie, Nae correspondem a título honorífico que precede o nome pessoal da kpojito. Kpojito, informa Bay (I995), era um posto oficial no antigo Daomé, um cargo que existiu a partir de certo momento da história do reino, ${ }^{61}$ até sua extinção no começo do século XX. Denominava a mulher parceira do rei no poder, considerada a mais rica e poderosa do reino. E, segundo a autora, uma das poucas certezas a esse respeito (Bay, I995) (22 $^{\text {é que }}$ aquelas nomeadas para o cargo tinham sido esposas do antecessor daquele que as convocava para ocupá-lo. Era nessa condição que elas se tornavam progenitoras simbólicas do novo rei: "Na perspectiva daomeana, a questão da relação biológica entre a kpojito e seu par masculino real é irrelevante [...] Cada rei substitui o primeiro ancestral, e a kpojito ergue-se no lugar de sua mãe" (Bay, I995: I2).

Ao reinstaurar a cada novo reino o tempo ancestral, a história do antigo Daomé traz consigo a natureza cíclica dos mitos. A dinastia real reinava no mundo visível e no mundo das sombras povoado pelos ancestrais divinizados, fundadores míticos dos clãs e por espíritos poderosos e perigosos do século XIX (Bay, I995). Nascimento e morte eram passagens entre os dois mundos, e os sacrifícios, oráculos e preces (o transe pela mediação dos sacerdotes, creio eu também) eram formas da comunicação entre eles. A atribuição do cargo de kpojito era perpétua. A transmissão ritual do cargo a sucessivas gerações assegurava, por assim dizer, a permanência corporal viva da pessoa originalmente nomeada, num espelhamento perfeito entre os dois mundos. O nome atribuído à kpojito, bem como seu status, tornava-se, assim, permanente. Agontimé - as- 
sim nomeada como a sexta ocupante do cargo no Daomé pré-colonial (Bay, I995) - foi vista pelo viajante inglês John Duncan em I845 em saudação reverencial ao rei Ghézo (Bay, I998); e, segundo Costa e Silva (2004: I04), "cinco anos depois Frederick Forbes, diante do túmulo da mãe de Guézo, assistiu à dança ritual de uma senhora que detinha o título de kpojito e o nome de Agontimé"; e ainda, I5 anos depois, outro viajante, Richard Burton, viu a kpojito Agontimé desfilar diante do rei. Para Bay (I995), a Agontimé de Ghézo era uma mulher que se notabilizou por seus poderes rituais, mas tendo sido vendida para o tráfico além-mar bem antes do reinado de Ghézo, claramente não estava envolvida na luta que precedeu sua ascensão ao poder. "A escolha de Ghézo por uma mulher que se acreditava estar vivendo no hemisfério ocidental simbolizava as fontes de apoio efetivas do rei, os mercadores do tráfico de Ajudá, e a sua escolha pode mesmo ter sido um esforço intencional de sinalizar o interesse de contatos mais próximos com o Brasil". ${ }^{63}$ Costa e Silva (2004: I03) de sua parte também pondera: "Num sistema polígamo como o dos fons, no qual o filho de uma das várias esposas de um homem tinha por mãe todas e cada uma de suas mulheres, Guézo poderia ter escolhido qualquer das cônjuges para rainha-mãe". Talvez por simbolizar a inimizade com Adandozan, Ghézo a quis como parceira no poder e mandou procurá-la nas Américas". Nenhum dos relatos disponíveis estabelece ou menciona qual teria sido o seu lugar de destino. As plausíveis razões da escolha de Ghézo permanecem especulativas. E, embora saibamos que aquela esposa de Agongono, mais tarde eleita rainha-mãe por Ghézo, foi vendida aos negreiros atlânticos por Adandozan, seu destino efetivo e a busca por ela nas Américas permanecem obscuros.

A inalcançável verdade insiste, entretanto, em ser perseguida. Em I98I, Costa e Silva visitou com Sergio Ferretti a Casa das Minas de São Luís do Maranhão e ouviu as mães de santo ressaltarem, "sem jamais mencionar o nome de fundadora do santuário" (Costa e Silva, 2004: I04), ${ }^{64}$ que aquelas que o estabeleceram eram todas africanas tendo chegado ao Maranhão no mesmo navio. Ele prossegue (Costa e Silva, 2004: I04): "O que coincide com a lembrança que se guarda no Daomé, de que Agontimé teria sido vendida junto com 63 de suas dependentes e servidoras". ${ }^{65}$

Se a existência da kpojito daomeana Agontimé pode ser registrada e estabelecida, a vida da esposa de Agongono, deportada para as Américas por Adandozan, cujo nome à época permanece desconhecido, parece destinada a ser para sempre um mistério a escapar não só da história como até mesmo do mito. Talvez seja mesmo um segredo guardado para sempre pelos voduns que não mais dançam na Casa das Minas de São Luís do Maranhão. 
Em 8 de fevereiro de 20I5, morreu a última chefe da Casa, dona Deni Prata Jardim, com 89 anos. Um neto de sua antecessora, mãe Amélia, tocador de tambor, mantém atualmente a agenda cultural da Casa das Minas que, como patrimônio brasileiro, prossegue aberta à visitação. A festa do Divino Espírito Santo e as festas juninas, tradicionais no calendário festivo da Casa prosseguem, ${ }^{66}$ porém os rituais religiosos do culto aos voduns cessaram. O culto aos voduns, entretanto, certamente se mantém em outros centros religiosos do país. Como assinalou Ferretti (I986), são numerosos os terreiros de tambor de mina em São Luís, e foram intensos os contatos mantidos entre o povo da Mina por todo o Maranhão e com outros estados, como Pará, Ceará, Pernambuco, Bahia, Brasília, Rio de Janeiro, São Paulo. Os voduns ancestrais da realeza daomena, entretanto, não dançam mais no Maranhão; permanecem, porém, cultuados no Benim, na outra margem do Atlântico, de onde vieram outrora.

Oriundo de família kardecista, Sergio Ferretti teve educação católica. Na entrevista concedida a Vagner Silva (publicada neste mesmo número), ele nos diz, com timidez, que queria ser monge beneditino, que na Casa das Minas se sentia algumas vezes como se estivesse no mosteiro, pois sempre apreciou nas religiões o gosto pela liturgia (ver também Silva, 2000). Foi durante seus estudos na universidade católica de Louvain, na Bélgica, que a leitura do livro de Roger Bastide lhe despertou o interesse pelas religiões afro-brasileiras. A militância na Juventude Universitária Católica levou-o ao Maranhão em I963/I964. Nos anos I970, depois de continuar a formação no exterior e de intensa atuação no centro de pesquisas da Conferência Nacional dos Bispos Brasileiros, para lá voltou como professor. Lá conheceu e casou-se com Mundicarmo, sua companheira de uma vida em que as pesquisas de ambos eram partilhadas no cotidiano. ${ }^{67}$ Lá engajou-se na construção institucional de museus e centros culturais, participou ativamente da Comissão Maranhense de Folclore, da entrada das ciências sociais na graduação e pós-graduação universitárias. Pesquisou a cultura popular maranhense de modo permanente, mas interessou-se particularmente pelas religiões e, entre elas, pela experiência religiosa da Casa das Minas do Maranhão. Creio que esse interesse resultou da confluência do cientista social, pesquisador incansável e generoso anfitrião, com seu ecumenismo. Ferretti viveu intensamente o encontro entre religiões, pesquisou no encontro entre religiões e no encontro entre religião e ciência. Pois, se para ele (Ferretti, I985: 56) a formação científica e a religiosa requeriam a mesma prolongada convivência e a mesma lenta e gradual absorção de procedimentos adequados, as diferentes religiões sabiam dialogar por entre as questões existenciais mais profundas das distintas sociedades humanas, como os mistérios da vida e da morte. 
Maria Laura Viveiros de Castro Cavalcanti é professora do Programa de PósGraduação em Sociologia \& Antropologia da UFRJ. Pesquisadora de festas e rituais da cultura popular contemporânea, dos estudos de folclore e da história da antropologia, das relações entre narrativa, ficção e escrita etnográfica; entre seus trabalhos recentes estão Carnaval, ritual e arte (2015) e a organização com Joana Corrêa da coletânea Enlaces: estudos de folclore e cultura popular (2018). 


\section{NOTAS}

I Mundicarmo Ferretti, com quem conversei diversas vezes por telefone, enviou-me material precioso para a redação deste trabalho. Ao longo do percurso, as conversas com Yvonne Maggie, Vagner Silva, Joana Corrêa, Mariza Soares, Alberto da Costa e Silva e Wilmara Figueiredo foram não só prazerosas como decisivas para a direção do argumento que desenvolvo. Peter Fry e André Botelho contribuíram com leitura atenta e generosa. A todos, e aos pareceristas deste artigo, meu obrigada.

2 A data da edição francesa - L'Animisme fétichiste des nègres de Bahia - é I900. O livro chamou a atenção da Escola Sociológica Francesa, então empenhada no estudo comparativo das religiões de distintas civilizações e dedicada a estabelecer o estudo da religião como um fato social. Marcel Mauss (I90I) resenhou-o em L’Année Sociologique. A edição em português de 1935 tem prefácio e notas de Arthur Ramos. Em 2006, a Editora UFRJ lançou reedição com facsímile desse conjunto de artigos de Nina Rodrigues publicados em I896 e I897 na Revista Brasileira, com apresentação e notas de Yvonne Maggie e Peter Fry (2006).

3 A bibliografia antropológica acerca das religiões afro-brasileiras é extensa e densa, não havendo aqui nenhuma intenção de dela dar conta. Busco apenas situar a singularidade da Casa das Minas de São Luís do Maranhão nesse contexto. Para um estado da arte desses estudos entre os anos I900 e I960, ver Silva (2002). Vale destacar, nesse vasto campo bibliográfico, o trabalho de Dantas (I988), que analisou os caminhos ideológicos e sociológicos da construção da ideia de uma "pureza nagô", entendida como a valorização de certa tradição religiosa afro-brasileira que se teria preservado mais íntegra do que as demais no processo das adaptações e transformações que perpassaram as religiões de origem africana no país. Tal ideia produziu em trabalhos intelectuais importantes, como o de Roger Bastide (I97I), muitos preconceitos com relação a formas religiosas consideradas mais "misturadas", como a umbanda e a macumba, por exemplo. Para uma crítica consistente a esse aspecto do trabalho de Bastide, ver Monteiro (1978). Ver também Cavalcanti (2012a). Para um exame da obra de Bastide, ver Peixoto (2000). 
4 A Pacotilha (I887). São Luís, ano II, n. I50. O mesmo jornal publica também, em 4 de agosto de I900, o convite feito ao "povo em geral" para a morte do Bumba meu Boi Está na Fama, na casa das Minas, na rua de São Pantaleão. No exemplar de 4 de julho de I905, o versinho "Rufa sonoro o tambor/Lá pela Casa das Minas" integra o anúncio de um periódico.

5 As datas para o estabelecimento da Casa das Minas são hipotéticas Na opinião de Ferretti (1985: 277), a Casa das Minas teria sido fundada na primeira metade do século XIX, provavelmente entre as décadas de I820 e I840, durante o período das guerras de independência, das diversas revoltas de escravos, da Balaiada, no Maranhão. Os testemunhos de memória obtidos por Ferretti acerca da trajetória da Casa alcançavam os anos I880. Ver também nota 25 .

6 Sergio Figueiredo Ferretti nasceu no Rio de Janeiro em I937 e faleceu em São Luís do Maranhão em maio de 2018. Vagner Silva (2018) publicou seu obituário no Anuário Antropológico. O número 36 da revista Inovação, da Fundação de Apoio à Pesquisa do Maranhão (Fapema), ano Io, 2018, homenageou Sergio Ferreti com caderno de fotos; relato de sua trajetória pessoal; entrevista com Mundicarmo Ferretti, sua esposa e também pesquisadora, que com ele compartilhou muitos de seus interesses; depoimentos do filho André Ferretti, do antropólogo português João Leal, do aluno Thiago dos Santos; e anúncio do resultado do Prêmio Sergio Ferretti.

7 Como destacado por Ferretti, antes da publicação de seu primeiro trabalho, há a monografia de mestrado de Maria Amália Pereira Barretto (I977) na Fundação Escola de Sociologia e Política de São Paulo. O primeiro livro de Ferretti (I985) resultou de sua dissertação de mestrado, defendida no Programa de Pós-Graduação em Antropologia Social da Universidade Federal do Rio Grande do Norte, em I983. O segundo livro (Ferretti, I995) resulta de sua tese de doutoramento, defendida no Programa de Pós-Graduação em Antropologia Social da Universidade de São Paulo, em I99i.

8 A Casa foi inscrita no Livro de Tombo Histórico e no Livro de Tombo Arqueológico, Etnográfico e Paisagístico do 
Iphan em fevereiro de 2005. O site do Iphan (www.iphan. gov.br) e o do Museu Afro Digital (museuafro.ufma.br) disponibilizam vídeos, artigos e fotos a respeito do tema. Essas inscrições integram o processo de expansão do conceito de patrimônio cultural por parte do Iphan, iniciado já em I985, quando a serra da Barriga, em Alagoas, onde se situa o importante quilombo de Palmares, foi declarada área protegida. Em I986, o Terreiro da Casa Branca, um dos mais antigos centros de cultos afro-brasileiros da Bahia (Velho, 2006), foi declarado Patrimônio Cultural Brasileiro. Essas decisões deram substância a um conceito mais amplo de patrimônio cultural. Abriram também caminho para a presença do patrimônio cultural imaterial (PCI) na Constituição Brasileira de I988, que culminou com a instauração das políticas públicas de PCI a partir do decreto presidencial de 4 de agosto de 2000 (Fonseca, I997; Tamazo, 2006; Cavalcanti, 2008).

9 Ver também Ferretti, I985: I3. Verger (I990: I5I): “a expressão 'negro mina' ou 'negro da costa da Mina', encontrada nos documentos dos séculos XVII e XVIII, era a abreviação da expressão 'negro da costa situada no leste do Castelo de São Jorge de Mina', ou seja, 'oriundo da costa dos escravos', situada entre o rio Volta e o rio Lagos".

Io Arthur Ramos grafava gêge, conforme a grafia da época, ao passo que a grafia atual para esse grupo étnico/linguístico consagrou o jêje. Aproveito esta ocorrência para esclarecer o procedimento adotado com relação à grafia de inúmeros termos que bem expressam as dificuldades da tradução cultural entre diferentes sistemas linguísticos e fonéticos para a escrita em línguas também diversas: a dos Fon, o francês, o inglês, o português em suas diferentes versões nacionais. Diversas classes de palavras encontram-se aqui abarcadas. Há os nomes do país - Dahomey, Danxomê, Daomei, Daomey, o Daomé na grafia adotada. Há aqueles de localidades ou regiões africanas, como Uidá, Ouidah, Whydah, Juda, Judá, Fida ou Ajudá na grafia adotada; ou ainda Abomey, Abomé na grafia adotada. Variam também bastante, por vezes dentro dos textos de um mesmo autor, a grafia dos nomes próprios dos personagens nas narrativas estudadas: Agonglo ou Agongono; Adanzan ou Adandozan; Agontime, Agontimè ou 
Agontimé; Dossouyévo ou Dossou Yovo; Ghèzo, Gezo ou Ghézo. Para não confundir o leitor, e como traduzo livremente as diferentes citações transcritas, optei por abrasileirar a pronúncia desses termos na maneira de grafá-los e usá-los desse modo em meu próprio texto.

I I Em I996, a Universidade Federal do Maranhão reeditou uma versão revista e ampliada do livro, a Editora e Dis tribuidora Pallas, do Rio de Janeiro, republicou-o em 2009. Nessa primeira pesquisa, Ferretti (1985: 17) comenta ter realizado "a transcrição parcial de uma centena de letras coletadas num repertório com talvez cerca de mil cânticos diferentes, que são utilizados regularmente pelo grupo e que pretendemos futuramente comentar".

I2 Posteriormente, Ferretti (2013) publicou a esse respeito reflexão sobre a possibilidade de o longo declínio da Casa das Minas do Maranhão ser um caso de "suicídio cultural".

I3 Vale observar que, desde seu primeiro estudo, Ferretti (1985: 2I3) ressaltou também a forte influência do espiritismo kardecista na Casa das Minas. Uma das fontes importantes sobre a memória histórica da Casa das Minas utilizada por ele é o autor espírita Waldemiro dos Reis (s.d.). Sobre o espiritismo kardecista, sua grande presença entre as camadas médias brasileiras e seu papel mediador entre a tradição religiosa católica e as tradições afro-brasileiras, ver Cavalcanti, I983 e I990.

I4 Há ainda a análise da cerimônia fúnebre, denominada Tambor de Choro e a análise da chamada Festa Grande, que, já em desuso, teria sido realizada com regularidade entre I943 e I962 a cada quatro ou cinco anos (Ferretti, I995)

I5 A ideia de origem de fundo culturalista e mesmo difusionista, muito criticada entre os anos 1970 e I990 na antropologia brasileira, perdura em nossos dias refraseada na expressão "religiões de matriz africana". Num contexto de expansão das seitas pentecostais e, muitas vezes, conflitos com elas, o termo parece operar sobretudo como forma de valorizar uma tradição cultural que integra a dança, o canto e o ritmo na experiência religiosa do transe.

I6 Lévi-Strauss já assegurou que, sim, certamente, sua monumental elaboração da mitologia das populações indíge- 
nas americanas bem pode ser entendida como uma versão a mais do próprio corpus que analisa (Lévi-Strauss, 20II).

I7 Em 2008, por ocasião de convênio realizado entre o Programa de Pós-Graduação de Sociologia e Antropologia/ IFCS/UFRJ e a Pós-Graduação em Ciências Sociais da UFMA (Ramalho \& Ferretti, 2009) ressaltei a contribuição de Sergio Ferretti para a construção de diversos espaços culturais e acadêmicos, bem como para o ingresso dos estudos de folclore e das culturas populares no rol dos temas de interesse universitários no Maranhão (Cavalcanti, 20I2b).

I8 Ferretti reúne e comenta nos livros citados informação detalhada acerca da história da Casa; ver especialmente Ferretti (I985, capítulo I). A seleção bibliográfica feita aqui, interpretações e comentários são, obviamente, de minha inteira responsabilidade.

I9 O estudo de Nunes Pereira teve uma segunda edição ampliada, publicada em 1979, estimulada por Bastide, quem, por sua vez, elaborara reflexões teóricas com base nos dados de Nunes Pereira em diversos trabalhos (Ferretti, I985: 23-24). Para Ferretti (I985: 4I), entretanto, os dados do próprio Bastide (I97I) relativos à Casa das Minas seriam pouco precisos com relação às informações de campo, e a contribuição mais relevante de Nunes Pereira "foi sem dúvida a que apresentou em I947, nas setenta páginas da primeira edição. Seu trabalho atual é prejudicado por deficiências de revisão editorial" (Ferretti, I985: 24).

20 A pesquisa de Octávio da Costa Eduardo, realizada entre novembro de 1943 e junho de I944, foi patrocinada pelo Museu Nacional do Rio de Janeiro, graças ao empenho de Heloisa Alberto Torres. O ano acadêmico de I944-I945 no Program of Negro Studies do Departamento de Antropologia da Northwestern University foi apoiado pela Fundação Rockefeller. Recursos da Escola Livre de Sociologia e Política de São Paulo e da Fundação Rockefeller viabilizaram a publicação da pesquisa. Para o papel da Escola Livre e da atuação de Donald Pierson na formação pós-graduada dos estudantes, ver o depoimento de Eduardo (200I).

2 I O texto resulta de comunicação apresentada à Sociedade Brasileira de Antropologia e Etnologia, no Rio de Janeiro, em sessão de II de agosto de I944. 
22 Valorizam-se o rastreamento das sobrevivências religiosas, identificadas por meio da comparação entre termos linguísticos, de possíveis adulterações e sincretismos, da proveniência étnica de seus portadores encontrados em diferentes partes do Brasil.

23 A feitoria de gonjaís ou de vodunsi-gonjaí: "filha de santo feita completa, que recebia vodum e uma que estivesse mais avançada no processo do que as demais" (Ferretti, I985: 29I). Com base em conversas e depoimentos com as mães de santo da casa, Ferretti elencou várias razões para a não feitoria de gonjaís: desde a morte sucessiva de gonjaís mais velhas iniciadas junto com Andresa Maria, conflitos nas sucessões, até a falta do conhecimento adequado, a carência de recursos financeiros, migrações, dificuldades enfrentadas pela Casa na legalização da posse do prédio. Ferretti (1985: 67) informa que, de acordo com alguns, mãe Andresa morreu aos 95 anos, com outros, aos I02. Andresa Maria teria sido preparada na penúltima iniciação da Casa, por volta de I895 (Ferretti, I985: 63). A relação das filhas de santo iniciadas junto com Andresa Maria pode ser encontrada na nota I da página 63; e a nota 2 da página 66 traz a relação das I 8 vodunsi gonjaí preparadas na última feitoria de I9I3-I9I4. A Casa teve seu Estatuto redigido em I980 por iniciativa de dona Celeste, que, em 1985, dançava na casa há mais de 30 anos (Ferretti, I985: 82). Para os esforços de localização original da Casa, vale remeter à nota 5 de Ferretti (I985: 85).

24 O jornal Pacotilha/O Globo, de São Luís do Maranhão, de 9 de março de I953, publicou extensa matéria intitulada “Segredos e mistérios da Casa das Minas", pelo repórter Nonato Masson e fotos de Dreyfus Azoubel. O número pode ser acessado na hemeroteca digital da Biblioteca Nacional, e traz fotos e depoimentos de mãe Andresa e demais membros da Casa.

25 Pegi = também fundamento, "quarto dos segredos", "lugar onde se localizam rituais reservados e onde se conservam importantes objetos e onde ficam os assentamentos - árvore ou pedra que recebe a força do vodum e representa a divindade" (Ferretti, I985: 284). Para Ferretti (1985: 58), o termo contrabando referir-se-ia no Brasil aos "escravos desembarcados após I83i, ano da primeira lei que proibiu 
o tráfico negreiro e que foi violada por cerca de vinte anos". Essa datação, entretanto, diverge da suposição da chegada em fins do século XVIII de cativos daomeanos, possíveis membros da família real, vendidos aos negreiros pelo rei Adandozan quando de sua tomada do poder; e contradiz a hipótese da fundação da Casa das Minas por Nã Agontimé, formulada por Verger e à qual logo nos voltaremos.

26 Nina Rodrigues, Manuel Querino, Edison Carneiro teriam identificado na Bahia traços de tradições e divindades jêjes, e mesmo o termo vodu, que Nina Rodrigues afirmara inexistir na Bahia. Mas seriam ainda sempre traços (Ramos, 1947: 7). Pesquisas mais recentes, como as de Parés (2006), Duarte e Carvalho (2006), e o relato de Duarte (2018) vêm, entretanto, atestar a presença relevante das tradições jêjes na Bahia.

27 De acordo com Arthur Ramos (I947: Io), embora o trabalho de Nunes Pereira requeresse complementações, ele revelaria "o essencial para a reconstituição de um corpo homogêneo de práticas voduns num ponto norte do Brasil, de franca influencia daomeiana". O nome que esse grupo recebeu foi Negros Minas ou Minas Jêje.

28 Nessa e nas demais citações de obras em idioma estrangeiro, a tradução é minha.

29 Para Ferretti (1985), que ressaltou o fato de a maior parte do livro de Eduardo se dedicar ao estudo da religião, essa pesquisa seria a principal tentativa de estudo científico dos cultos afro-maranhenses. Eduardo conviveu com a Casa durante seis meses quando ainda estariam vivas importantes líderes do culto.

30 A fonte de Eduardo é Herskovits (1938). Vale observar que Le Hérissé (2014) será uma fonte importante para Verger, que não se refere, entretanto, a Herskovits, nem a Burton e Skertchly, indiretamente citados por Eduardo.

3I Segundo Ramos (I947: IO-II), não haveria dúvida da proveniência daomeana do grupo da Casa das Minas "menos pelas evidências históricas, que são quase nulas, que pelo critério da comparação cultural. Os termos correntes da Casa das Minas são daomeianos".

$32 \mathrm{Na}$ Casa das Minas, o panteão das divindades estaria or- 
ganizado em três famílias: "a de Davise ou Daomé, que não encontra correspondência com crenças no Daomé; a família Da ou Danbira, que tem os mesmos atributos do panteão daomeano Sagbata; e o grupo Kevioso. Esses são termos genéricos para grupos de divindades assim como suas contrapartidas daomeanas" (Eduardo, I948: 76).

33 Remeto o leitor interessado a todo o trecho de Eduardo (1948: 77).

34 Daomé já era desde 1892 protetorado francês; tornou-se independente em I930 como República do Daomé e passou a chamar-se República do Benim em I975. A descendência da Casa Real do Daomé bem como o culto aos voduns, entretanto, perduram até os dias de hoje.

35 Embora o pressuposto das pesquisas fosse a natureza harmoniosa da experiência civilizatória brasileira, o projeto Unesco de relações raciais produziu um valioso conjunto de pesquisas que revelaram desigualdades, tensões, conflitos e a existência do preconceito e da discriminação racial no Brasil. Ver a respeito Maio (I999, I998).

36 Seguindo esse interesse, Pierre Verger escreveu em I968 o clássico Flux et reflux de la traite des nègres entre le Golfe de Bénim et Bahia de Todos os Santos, publicado no Brasil pela Ed. Corrupio em I987. Manuela Carneiro da Cunha (I985), em seu também clássico Negros estrangeiros. Os escravos libertos e sua volta à África, enfocou o retorno dos libertos brasileiros a Lagos, na Nigéria, enquanto Marianno Carneiro da Cunha (I985) se debruçou sobre as influências arquitetônicas brasileiras nessa mesma cidade.

37 Uma tradução em português desse texto foi publicada em I978 na Revista Maranhense de Cultura, da Fundação Cultural do Maranhão criada nos anos 1970 por Domingos Vieira Filho, intelectual e folclorista, então presidente da Fundação Cultural do Estado do Maranhão, com Sergio Ferretti como diretor do Departamento de Assuntos Culturais (ver a respeito Cavalcanti, 20I2b; Braga, 2000; Matos, 20I9). O exemplar, contudo, não nomeia o tradutor e nem indica a referência do original. Um problema de revisão editorial tende também a confundir o leitor. Como veremos, Verger constrói sua hipótese com base em diferentes fontes, cujos trechos transcritos por ele são devidamente aspeados ao início e ao final na versão original. 
No entanto, na versão em português, há problemas relevantes na indicação das aspas. O trecho final do artigo em especial, no qual Verger articula os passos de seu argumento e o conclui, segue aspeado como se fosse sequência de transcrições da última fonte mencionada. Por essa razão, utilizo como referência a versão original cujas citações traduzo livremente do francês.

38 Da seção "Brasil", com dez artigos, participam: Roger Bastide, com "L’Axêxê"; Edison Carneiro, com "Singularidades dos quilombos"; Octávio da Costa Eduardo, com "O tocador de atabaque nas casas de culto afro-maranhenses"; Gonçalves Fernandes, com "O sincretismo gêge-nagô-católico como expressão dinâmica dum sentimento de inferioridade"; Gilberto Freyre, com "A propósito de relações entre raças e culturas no Brasil"; Joseph H. Greenberg, com "An application of New World evidence to an African linguistic problem (Hausa); Melville J. Herskovits, com "The Panam, an Afrobahian religious rite of transition"; Carlos Ott, com "O negro baiano"; Donald Pierson, com "Africans and their descendants at Bahia, Brasil"; e Pierre Verger com o artigo em pauta que não traz referências bibliográficas completas. Além da seção sobre a África, que abre o volume com o dossiê de Verger "Influence du Brésil sur le Golfe de Benin", as demais seções dedicam-se a Cuba (três artigos por William Bascom, Lydia Cabrera e Romulo Lachatañeré), Guiana Holandesa (um artigo por Melville Herskovits), Haiti (oito artigos por Lorimer Denis, Michel de Leiris, Pierre Mabille, Louis Mars, Odette Mennesson-Rigaud, Alfred Métraux, Yvonne Oddon e Jean Price-Mars), Uruguai-Argentina (um artigo por Ildefonso Pereda-Valdes) e Estados Unidos (um artigo, por Ruth Landes).

39 O site da Fundação Pierre Verger disponibiliza sua biografia, depoimentos, entrevistas e a relação completa de sua obra publicada. Pierre Verger nasceu na França em I902 e morreu na Bahia em I996, onde chegara em I946, depois de 14 anos de viagens mundo afora que já o haviam celebrizado como fotógrafo, e torna-se adepto do candomblé. Em I948 segue para pesquisar os rituais religiosos africanos com uma bolsa do Ifan sob supervisão de seu diretor, Théodore Monod. Inicia, então, suas atividades de pesquisador com a produção de livros e artigos dentre os quais se destaca o tema das conexões religiosas entre Brasil e África. Ver também Silva (2000). 
40 Pesquisas posteriores às quais recorrerei adiante permitem relativizar essa informação.

4I O livro de Hazoumé (I937) bem expressa essa perspectiva. Parés (2013: 297) comenta como Adandozan teve sua memória apagada depois de destronado por Ghézo, sendo "recorrentemente representado como um déspota cruel e sanguinário". Devo confessar que essa é a impressão que fica da leitura da carta, datada de 9 de outubro de I8Io, de Adandozan a dom João, transcrita no artigo citado de Parés. Para um exame da tradição oral que retrata Adandozan como tirano sádico, ver Costa e Silva (2004: 84-85), que a relativiza, entretanto, por uma possível acentuação histórica posterior.

42 Le Hérissé viveu entre I876 e I953. Ver <http://cths.fr/an/ savant.php?id=I25398>, site no qual obtive essas informações.

43 Paul Hazoumé (I890-I980) é considerado o patriarca da literatura negroafricana de expressão francesa com o romance Doguimici (<https://en.wikipedia.org/wiki/Paul_Hazoumé>), um documento histórico e etnológico oriundo de 25 anos de contato com os anciãos do antigo Daomé (Hazoumé, 1938)

44 O capítulo IV de Hazoumé (I937) detalha as articulações do pacto de sangue firmado entre o príncipe Gapê e Francisco Félix de Souza, o famoso mercador de escravos brasileiro, que levaram o primeiro ao poder com o nome de Ghézo. Costa e Silva (2004) escreveu um belo livro sobre o mercador (Chaca Ajinacou era o seu nome africano) que nasceu em I754 - conforme assegura a descendência de Francisco Félix cujo bicentenário de nascimento foi por ela comemorado em 4 de outubro de I954- ou I768, conforme indica um comerciante inglês que com ele tratava pessoalmente. Ele morreu em I849 e teria chegado na África como comandante da fortaleza de Ajudá em I788 ou em I793, segundo diferentes versões. O dossiê de Verger (I953b), que abre o número do Ifan já citado, traz informações sobre o mercador. Em sua obra precursora, Nina Rodrigues (1977: 28) já chamara atenção para o papel crucial do mercador negreiro na história do tráfico brasileiro: "o mestiço fluminense em que ela se encarnou num período de quase cinquenta anos", associando-o por sinal à "reputação de grandeza conquistada pelo rei Ghézo" (Nina Rodrigues, I977: 30). Costa e Silva (2004: I2) 
corrige a naturalidade de Francisco Félix: ele seria baiano, tal como ele mesmo atestou em documentação disponível; e confirma seu estreito relacionamento, que perdurou por toda a vida, com o príncipe Gapê/rei Ghézo.

$45 \mathrm{O}$ assunto é retomado no capítulo IV de Hazoumé (I937: 27 , nota 2), sobre as vantagens políticas do pacto de sangue. Para o autor, a linhagem dos reis ancestrais teria protegido Gapê, tornando Adandozan surdo aos conselhos de seus aliados para eliminá-lo. Adandozan não o considerava um rival em potencial, e o príncipe teria tido mesmo a liberdade de percorrer o reino. Nessa direção - e em um ambiente em que as forças espirituais participam como atores da composição da narrativa histórica - é interessante observar como, ao tomar o poder em I8I8, Ghézo não eliminou, por sua vez, Adandozan que, como informa Costa e Silva (2004: 87) teria ficado retido em aposentos exclusivos no palácio real, tendo, aliás, sobrevivido a Ghézo.

46 Esse livro está disponível no catálogo eletrônico do Instituto de Estudos Brasileiros da Universidade de São Paulo.

47 Hazoumé (I937, capítulo IV) também refere-se a Dossouyévo.

48 Os embaixadores, entretanto, depois de esperar durante três anos na Bahia, teriam retornado ao Daomé sem conseguir alcançar o Rio de Janeiro (Verger, I953a: 158).

49 Chama a atenção a repetição por três vezes do número três, um procedimento muito recorrente em relatos míticos e que vem acentuar a oralidade das narrativas de memória.

50 Verger (I953a: I60) apresenta a lista dos nomes citados a ele por Andresa e a equivalência estabelecida por Mivede le Zomadonoussi, sacerdote de Zomadonu em Abomé na África, que detém "poder de jurisdição sobre a totalidade dos sacerdotes animistas do lugar" - fato também mencionado no artigo posterior de Verger (I990: I52).

5I Fatumbi foi o nome atribuído pelo oráculo de Ifá a Verger em sua iniciação no Benim.

52 Montello (I975: 485) nos fala de suas fontes de inspiração num pósfácio intitulado "História deste livro": "o que primeiro me aflorou à consciência, inspirando-lhe a germinação misteriosa, foi o ruído dos tambores da Casa das 
Minas, que ouvi em São Luís, nos idos de minha infância e juventude". Reconhece sua dívida maior para com Nunes Pereira: "Graças a seu livro [...] pude penetrar nos mistérios do querebentã negro, em São Luís. Assim, quando ali procurei Maria Cesarina, nas várias vezes em que a visitei para recolher a atmosfera de seus ritos, já eu tinha sobre eles a informação exata [...] Sentei no comprido banco de pau em que sentaria o Damião [seu personagem central], alonguei o olhar para o amplo terreiro onde se esgalha a cajazeira sagrada, e tive a antevisão das velas acesas enquanto retumbam os tambores e dançam as noviches vestidas de branco" (Montello, I975: 487). Para uma descrição da Casa, ver Montello (1975: 199-205).

$53 \mathrm{Na}$ noite de 2 de setembro de 2018 , um incêndio calamitoso se abateu sobre o Museu Nacional, instituição integrante da Universidade Federal do Rio de Janeiro, localizada na Quinta da Boa Vista, antiga residência imperial. A tragédia não fez vítimas humanas, mas destruiu cerca de vinte milhões de itens incorporados ao longo de 200 anos ao valioso acervo. Entre eles, a coleção de objetos daomeanos que tanto interessou a Verger e a historiadores posteriores. Ela pode, entretanto, ser ainda visualizada: é a seção II, intitulada Diplomacia da Amizade Brasil-Daomé, da exposição virtual Kumbukumbu: África, memória e patrimônio, acessível no site artsandculture.google.com. A historiadora Mariza Soares (20I4) coordenou, entre 2010 e 20I6, o projeto Africana que empreendeu o levantamento de todos os objetos africanos que compunham o acervo etnográfico do Museu Nacional (Soares \& Lima, 2013). No processo de pesquisa, com a colaboração de Ana Lúcia Araújo, esses objetos puderam ser cruzados com aqueles nomeados em uma carta - desconhecida por Verger quando da redação de Fluxo e refluxo (I987) e publicada por Parés (2013) (a carta I3 por ele transcrita) - datada de 9 de outubro de I8Io do rei Adandozan a dom João VI. Ver também a respeito Soares e Lima (2013). Soares (2014) analisou em detalhes a carta de Adandozan e observou sua narrativa particular que atestaria ter sido ela efetivamente ditada por ele ao intérprete que a redigiu.

54 Verger (I990) menciona em nota que, com um título mais longo, o artigo estaria destinado a compor o capítulo de um livro sobre São Luís do Maranhão a ser publicado pe- 
la Ed. Corrupio. Não encontrei nenhuma referência a respeito. Esse artigo veio a compor, entretanto, a primeira seção, denominada Na Agontimé, da Parte VII intitulada "Os que no Brasil permaneceram fiéis aos valores africanos", de Verger (1992).

55 Maurice Ahanhanzo Glélé (1974) é autor de Le Danxome: du pouvoir aja à la nation fon. Segundo Maurice Glélé, citado por Costa e Silva (2004: 87), em I838, já bem estabelecido como rei, Ghézo exclui da sucessão o filho de Adandozan, em favor de seu próprio filho, o futuro Glélé. Só então "Adandozan teria sido dessacralizado, seus familiares vendidos como escravos e seu nome excluído da lista dos reis, como se nunca tivesse existido". Não dataria de então também a eleição de Nã Agontimè como sua kpojito?

56 Silva (2000: 97-98) comenta a pequena participação de Pierre Verger no campo institucional acadêmico "inclusive pela aversão que demonstrava ao diálogo com intelectuais". Desse modo, "Sem a preocupação de travar nenhum diálogo teórico-acadêmico, Verger tornou-se um incansável pesquisador de campo em busca de detalhes cada vez maiores para compor suas minuciosas etnografias".

57 São I4 cartas ao todo enviadas nos reinados de Agongono, Adandozan e Ghézo. A correspondência integra o interessante assunto da diplomacia africana com as monarquias europeias no período do tráfico de escravos atlântico abordado por Parés (2013) e por Soares (20I4). Para o exame das embaixadas africanas como uma forma ritual de exposição pública de poder, ver Lara (200I), que examina aquela enviada em 1750 pelo rei Angome, do Daomé, à Bahia.

58 Sem, obviamente, os responsabilizar pelas interpretações e pelo uso que delas resultam.

59 Segundo Costa e Silva (2004: 4I), "No início do século XVIII, tinha-se Ajudá como o mais importante centro exportador de escravos do golfo do Benim. E, hoje, estima-se que $40 \%$ de todos os escravos - cerca de quatrocentos mil - que atravessaram o Atlântico, no primeiro quartel do Setecentos, foram ali embarcados". "Ao longo do Setecentos, o Recôncavo Baiano manteve-se como o principal destino dos escravos exportados pelo golfo de Benim. E entre I79I e I830, chegaram a ser endereçados à Bahia $75 \%$ dos embarques. A completar o quadro, já se sugeriu 
que $3 / 4$ dos navios brasileiros que demandavam a região recebessem alguma carga em Ajudá". Segundo o autor, a primazia de Ajudá devia-se ao fato de que lá, “desde a passagem do XVII para o XVIII, a comercialização de escravos e a assistência aos navios negreiros se mostravam melhor estruturadas do que em outros embarcadouros e com regras relativamente estáveis, num ambiente de certa segurança" (Costa e Silva, 2004: 44-45). Por sua vez, o predomínio dos navios portugueses nessa parte da costa deveu-se, segundo o autor, à apreciação dos africanos não só pelo ouro e outras mercadorias pelas quais se trocavam escravos, mas especialmente pelo fumo de rolo baiano, vindo do Brasil.

6o Para detalhes da disputa que envolve conspirações e violência entre os partidários concorrentes à sucessão, ver o capítulo 8 de Costa e Silva (2004). O padre católico Vicente Ferreira Pires visitou o rei Agonglo poucos dias antes de sua morte por envenenamento por uma mulher do palácio, partidária de um príncipe tido por irmão do rei. Uma das causas da conspiração seria a intenção de cristianização por Agonglo. Bay (I995: I8) refere-se ao estabelecimento do culto à divindade cristã em um dos altares do palácio real por uma das mulheres integrantes do palácio real Agonglo. O problema teria sido causado, entretanto, sobretudo pelo desejo de Angonglo batizar-se cristão, em uma estratégia de aproximação comercial com os portugueses. A coletânea Imagens da África, organizada por Alberto da Costa e Silva (20I2) traz dois trechos do livro de Ferreira Pires, que ofereceu a dom João, em I80o, o testemunho Viagem de África em o reino de Daomé, pormenorizado relato de sua missão junto ao rei Agonglo, iniciada em I796. O livro, de acordo com Costa e Silva, foi publicado por Clado Ribeiro de Lessa (I957). Um dos trechos relata as festas denominadas costumes do jirau, cerimônias anuais em que os daomeanos reafirmavam submissão e fidelidade aos reis, cujos ancestrais, em sinal de lealdade, recebiam sacrifícios humanos. Ver a respeito dessas festas também Bay (I995). Costa e Silva (2004) indica também o declínio de comércio em Ajudá na época como uma das causas da queda de prestígio do rei Agongono. O tráfico de escravos na costa atlântica só teria retomado impulso a partir de I820, do que muito se teria beneficiado Francisco Félix de Souza, o grande aliado de Ghézo. 
6I Bay (I995: Io) considera Adonon, associada ao rei Agaja (I7I6-I740), a primeira kpojito, embora relacione três antecessoras associadas aos reis anteriores (uma delas a mesma Adonon, associada a Akaba, o rei que precedeu Agaja). Ela assinala o quanto, na tradição daomeana, nomes são frequentemente citados para pessoas que teriam ocupado cargos anteriores à própria criação histórica conhecida a respeito de tais cargos, uma prática que em seus termos "ajudaria a enaltecer o sentido de imutabilidade das estruturas institucionais daomeanas" (Bay, I995: 9, nota 29). Para Bay (I995: 25) o cargo teria sido efetivamente criado nos anos I720 ou I730 como uma forma de legitimidade ritual para a linhagem Alladahonu como dinastia reinante do Daomé.

62 Bay (I998) escreveu também um livro sobre o assunto. No artigo citado (Bay, I995), ela assinala, contudo, o quanto tudo o que cerca as kpojito está envolto em enormes problemas de documentação, o que, de meu ponto de vista, se relaciona à natureza mítica da história daomeana transmitida primordialmente por tradições orais, transcritas para a maior parte das fontes escritas existentes. O que não quer dizer que os historiadores não tenham conseguido estabelecer relevantes fontes fidedignas a esse respeito nem tampouco que essa natureza mítica não traga relevantes informações se analisadas em seus próprios termos, o que se apresenta como um campo também a ser explorado por estudos antropológicos.

63 Bay (I998) menciona a hipótese de Verger, contrapondo fontes e outras versões narrativas. Para ela, a incerteza quanto ao destino de Agontimé é irrelevante do ponto de vista da história daomeana. Como um emblema da oposição ao rei posteriormente deposto por Ghézo, "Ela foi fixada como uma figura simbólica mais do que uma figura real na história do Daomé" (Bay, I998: I80).

64 Ferreti (I985: 59) já assegurava: "As filhas da casa desconhecem o nome de Nan Agontime e quase nada dizem sobre Maria Jesuína", nomeada pelos membros do grupo nos anos 1970 como a fundadora da Casa que adorava o vodun Zomadonu, daí Querebentan de Zomadonu - Casa de Zomadonu - o nome africano da Casa das Minas que dá título ao primeiro livro de Ferretti.

65 A referência de Costa e Silva é Herskovits, I938, v. 2, p. 64. 
Costa e Silva relatou-me em conversa (4/4/2019) na Academia Brasileira de Letras que, depois disso, como embaixador do Brasil na Nigéria acumulando a representação no Benim e sabedor do lento declínio religioso da Casa por conta da não iniciação plena de novas vodunsi, ele se empenhou e, com a participação de Sergio Ferretti e da Casa das Minas, obteve sucesso na designação de quatro adeptas que teriam o apoio do governo brasileiro para permanecer durante dois anos junto aos sacerdotes daomeanos de modo a completar todo o processo ritual iniciático. O governo do Benim de então, entretanto, não garantiu as condições de segurança e apoio necessárias para a permanência prolongada, comprometendo a realização do projeto, considerado por Costa e Silva uma dimensão relevante das relações diplomáticas entre Brasil e África.

66 Euzébio Pinto, que cuida atualmente da Casa, é o neto de mãe Amélia. Wilmara Figueiredo, pesquisadora da cultura popular maranhense, a quem agradeço essas informações, esclarece que o católico são João, cuja data se comemora no 24 de junho, associa-se à divindade mina Nochê Naé. É ela quem relata, por meio do e-mail trocado comigo no dia 3 de abril: "No dia 29 de junho, data que se comemora São Pedro, alguns grupos de boi, além de se apresentarem na Capela do Santo, também se apresentam na porta do terreiro em respeito à memória e simbologia da Casa, deixando bem claro o forte elo das brincadeiras de Bumba Meu Boi com o tambor de mina de um modo geral. [...]. O grande marco festivo da Casa continua sendo a Festa do Divino, que por longos anos foi comandada por Dona Celeste (falecida em 25/10/2010) em cumprimento da devoção da entidade Nochê Sepazim à Terceira Pessoa da Santíssima Trindade, o que denota a tradição secular da Festa do Divino na Casa das Minas". Mundicarmo Ferretti informou-me em comunicação pessoal que três vodunsi da Casa ainda estão vivas: Zobeilda, tia de Euzébio; Enedina, quase centenária, residente no Rio de Janeiro; e Elizabete (filha de Zobeilda), que teria dançado em junho de I985, por ocasião do Colóquio da Unesco em São Luís do Maranhão (Unesco, I986).

67 Ver, por exemplo, Mundicarmo Ferreti (I993, I989). 


\section{REFERÊNCIAS BIBLIOGRÁFICAS}

Barretto, Maria Amália Pereira. (1977). Os voduns do Maranhão. São Luís: Fundação Cultural do Maranhão.

Bastide, Roger. (I97I) [I960]. As religiões africanas no Brasil. São Paulo: Perspectiva.

Bay, Edna. (1998). Wives of the leopard: gender, politics and culture in the kingdom of Dahomey. Charlottesville: University of Virginia Press.

Bay, Edna. (1995). Belief, legitimacy and the kpojito: an institutional history of the "queen-mother" in precolonial Dahomey. Journal of African History, 36/I, p. I-27.

Braga, Ana Socorro Ramos. (2000). Folclore e política cultural. A trajetória de Domingos Vieira Filho e a institucionalização da cultura. Dissertação de Mestrado (antropologia). Universidade Federal do Maranhão.

Carneiro da Cunha, Manuela. (1985). Negros, estrangeiros. Os escravos libertos e sua volta à África. Rio de Janeiro: Ed. Brasiliense.

Carneiro da Cunha, Manuela. (1979). Etnicidade: da cultura residual mas irredutível. Revista de Cultura e Política, São Paulo, I/I, p. 35-39.

Carneiro da Cunha, Mariano. (1985). Da senzala ao sobrado: arquitetura brasileira na Nigéria e na República do Benin. São Paulo: Edusp.

Carneiro, Edison. (1964). Ladinos e crioulos: estudos sobre o negro no Brasil. Rio de Janeiro: Civilização Brasileira.

Carvalho, Marcos. (2006). Gaiaku Luiza e a trajetória do jeje-mahi na Bahia. Rio de Janeiro: Editora Pallas.

Cavalcanti, Maria Laura Viveiros de Castro. (2012a). Origens, para que as quero? Questões para uma investigação sobre a umbanda. In: Cavalcanti, Maria Laura Viveiros de Castro. Reconhecimentos. Antropologia, folclore e cultura popular. Rio de Janeiro: Editora Aeroplano, p. 38-69.

Cavalcanti, Maria Laura Viveiros de Castro. (2012b). Por uma antropologia dos estudos de folclore. O caso do Maranhão. In: Cavalcanti, Maria Laura Viveiros de Castro. Reconhecimentos. Antropologia, folclore e cultura popular. Rio de Janeiro: Editora Aeroplano, p. I48-I79. 
Cavalcanti, Maria Laura Viveiros de Castro. (2008). Patrimônio cultural imaterial no Brasil: estado da arte. In: Fonseca, Maria Cecília Londres (org.). Patrimônio imaterial no Brasil: legislação e políticas estaduais. VI. Brasília: Instituto Brasileiro de Educação e Cultura, p. II-36.

Cavalcanti, Maria Laura Viveiros de Castro. (I990). Espiritismo. In: Landim, Leilah (org.). Sinais dos tempos. Diversidade religiosa no Brasil. Rio de Janeiro: Instituto Superior de Estudos da Religião, p. I47-I56.

Cavalcanti, Maria Laura Viveiros de Castro. (I983). O mundo invisível. Cosmologia, sistema ritual e noção da pessoa no espiritismo. Rio de Janeiro: Zahar Editores.

Cavalcanti, Maria Laura V.C. \& Corrêa, Joana Ramalho Ortigão. (2018). Enlaces: estudos de folclore e culturas populares. Rio de Janeiro: Centro Nacional de Folclore e Cultura Popular.

Corrêa, Mariza. (1998). As ilusões da liberdade. Bragança Paulista: Edusf.

Costa e Silva, Alberto da (organização e notas). (2012). Imagens de África. São Paulo: Penguin.

Costa e Silva, Alberto da. (2004). Francisco Félix de Souza: mercador de escravos. Rio de Janeiro: Eduerj/Nova Fronteira. Costa e Silva, Alberto da. (I994). O Brasil, a África e o Atlântico no século XIX. Estudos Avançados, 8/2I, p. 2I-42. Curado A. D. Cortez da Silva. (I888). Dahomé. Esbôço geographico, historico, ethnographico e politico. Lisboa: Typ. do Comercio de Portugal.

Dantas, Beatriz Góis. (1988). Vovó nagô, papai branco. Usos e abusos da África no Brasil. Rio de Janeiro: Ed. Graal.

Duarte, Everaldo Conceição. (2018). Terreiro do Bogum. Memórias de uma comunidade jêje-mahi. Salvador: Ed. Solisnuna. Eduardo, Octávio da Costa. (200I). O processo de construção institucional. In: Kantor, Iris; Maciel, Débora \& Simões, Júlio. A Escola Liure de Sociologia e Política. Anos de formação, I933-I953. São Paulo: Escuta, p. 2I-25.

Eduardo, Octávio da Costa. (I948). The Negro in Northern Brasil. A study in acculturation. Monographs of the American Ethnological Society, XV. New York: J.J. Augustin Publisher. 
Ferretti, Mundicarmo. (I993). Desceu na guma: o caboclo do tambor de mina no processo de mudança de um terreiro de São Luís (A Casa de Fanti-Ashanti). São Luís: Sioge.

Ferretti, Mundicarmo. (1989). Rei da Turquia: o Ferrabrás de Alexandria? A importância de um livro na mitologia do Tambor de Mina. In: Moura, Carlos E.M. de (org.) Meu sinal está em teu corpo. São Paulo: Edicon/Edusp.

Ferretti, Sergio. (2017). Correspondência de Octávio da Costa Eduardo para Melville Herskovits (1943 - 1944). Revista Pós Ciências Sociais, I4/27, p. 213 - 229.

Ferretti, Sergio Figueiredo. (2013). O longo declínio da Casa das Minas do Maranhão: um caso de suicídio cultural? In: Conceição, Douglas Rodrigues da \& Moraes Jr., Manoel Ribeiro de (orgs.). Religião no Brasil. Ciência, cultura, política e literatura, v. I. Belém: Fonte Editorial, p. I67-I78. Ferretti, Sergio Figueiredo. (1995). Repensando o sincretismo. A Casa das Minas de São Luís do Maranhão. Edusp/Fapema. Ferretti, Sergio Figueiredo. (1986). As religiões de origem africana no Maranhão. In: Culturas Africanas: documentos da reunião de peritos sobre "As sobrevivências das tradições religiosas africanas nas Caraíbas e na América Latina", colóquio realizado em São Luís do Maranhão, de 24 a 28 de junho de I985, p. I56-I73. Unesco. Documento CC86/WS/37. Digital Library.

Ferretti, Sergio Figueiredo. (1985). Notas sobre Querebentan de Zomadonu. Etnografia da Casa das Minas. Coleção Ciências Sociais. Série Antropologia I. São Luís do Maranhão: Universidade Federal do Maranhão.

Fonseca, Maria Cecília Londres. (I997). O patrimônio em processo: trajetória da política federal de preservação no Brasil. Rio de Janeiro: Ed. UFRJ/Iphan.

Gleason, Judith. (I970). Agõtime: her legend. New York: The Viking Press.

Glélé, Maurice Ahanhanzo. (1974). Le Danxome: du pouvoir aja à la nation fon. Paris, Nubia.

Hazoumé, Paul. (1938). Doguimici. Paris: LeRose Librairien Éditeur.

Hazoumé, Paul. (1937). Le pacte de sang au Dahomey. Paris: Université de Paris/Institut d'Ethnologie.

Herskovits, Melville. (1938). Dahomey: an ancient west African kingdom, 2v. New York: Augustin Publishers. 
Lara, Silvia. (200I). Uma embaixada africana na América portuguesa. In: Jancsó, István \& Kantor, Iris (orgs.). Festa. Cultura e sociabilidade na América portuguesa. São Paulo: USP, V. I, P. I53-I65.

Leacock, Seth \& Leacock, Ruth. (1975). Spirits of the deep: a study of an Afro-Brasilian cult. New York: Anchor Books. Le Hérissé, Auguste. (20I4) [I9II]. L’Ancien royaume du Dahomey. Moeurs, réligion, histoire. Paris: Ed. Hachette Livre/ Bibliothèque Nationale Française.

Lessa, Clado Ribeiro de. (1957). Crônica de uma embaixada luso-brasileira à Costa d'África em fins do século XVIII, incluindo o texto da Viagem de África em o Reino do Daomé escrita pelo padre Vicente Ferreira Pires no ano de 1800 e até o presente inédita. São Paulo: Companhia Editora Nacional (Brasiliana).

Lévi-Straus, Claude. (20II) [I97I]. O homem nu. São Paulo: Cosac\&Naify.

Lévi-Strauss, Claude. (I976). O pensamento selvagem. São Paulo: Companhia Editora Nacional.

Maggie, Yvonne. (2015). No underskirts in Africa: Edison Carneiro and the 'lineages' of Afro-Brasilian religious anthropology. Sociologia \& Antropologia, 5/I, p. IOI-I27.

Maggie, Yvonne \& Fry, Peter. (2006). Apresentação. In: Nina Rodrigues, R. O animismo fetichista dos negros baianos. Rio de Janeiro: Ed. UFRJ, p. 9-25.

Maio, Marcos Chor. (I999). O projeto Unesco e a agenda das ciências sociais no Brasil dos anos I940/50. Revista Brasileira de Ciências Sociais, I4/4I, p. I4I-I58.

Maio, Marcos Chor. (I998). O Brasil no concerto das nações: a luta contra o racismo nos primórdios da Unesco. História, Ciências, Saúde - Manguinhos. Rio de Janeiro, 5/2, p. 375-4I3.

Matos, Elisene Castro. (20I9). Intérpretes da cultura popular e a produção de memórias no Maranhão. Tese de Doutorado. Programa de Pós-Graduação em Ciências Sociais/Universidade Federal do Maranhão.

Mauss, Marcel. (I90I). Nina Rodrigues. L’animisme fétichiste des nègres de Bahia. Année Sociologique, 5, p. 224225 .

Monod, Théodore. (1953) Préface. In: Les Afro-américains. Dacar: Institut Français de l'Afrique Noire. p. 7-8. 
Monteiro, Duglas Teixeira. (I978). Roger Bastide: religião e ideologia. Religião e Sociedade. Rio de Janeiro, 3.

Montello, Josué. (1975). Os tambores de São Luís. Rio de Janeiro: Livraria José Olympio Editora.

Nina Rodrigues, Raimundo. (2006). O animismo fetichista dos negros baianos. Apresentação e notas de Yvonne Maggie e Peter Fry. Rio de Janeiro: Ed. UFRJ.

Nina Rodrigues, Raimundo. (1977). Os africanos no Brasil. São Paulo: Companhia Editora Nacional. (Brasiliana, 9).

Nina Rodrigues, Raimundo. (I935). O animismo fetichista dos negros baianos. Prefácio e notas de Arthur Ramos. Rio de Janeiro: Civilização Brasileira.

Nina Rodrigues, Raimundo. (I900). L'animisme fétichiste des nègres de Bahia. Salvador: Reis \& Comp. Éditeurs.

Nunes Pereira. (1947). A Casa das Minas. Contribuição ao estudo das sobrevivências daomeianas no Brasil. Publicações da Sociedade Brasileira de Antropologia e Etnologia, Rio de Janeiro, I.

Parés, Luis Nicolau. (2013). Cartas do Daomé: uma introdução. Afro-Ásia, 47, p. 295-395.

Parés, Luis Nicolau. (2006). A formação do candomblé. História e ritual da nação jêje na Bahia. Campinas: Editora Unicamp.

Peixoto, Fernanda Areas. (2000). Diálogos brasileiros. São Paulo: Edusp.

Ramalho, José Ricardo \& Ferretti, Sergio (orgs). (2009). Amazônia. Desenvolvimento, meio ambiente e diversidade sociocultural. São Luís: Editora de Universidade Federal do Maranhão.

Ramos, Arthur. (I947). Introdução. In: Nunes Pereira. A Casa das Minas. Contribuição ao estudo das sobrevivências daomeianas no Brasil. Publicações da Sociedade Brasileira de Antropologia e Etnologia, Rio de Janeiro, I, p. 5-I4.

Reis, Waldemiro E. dos. (s.d). Espiritismo e mediunidade no Maranhão. São Luiz: editora desconhecida.

Silva, Vagner. (2018). Sergio Ferretti, conhecimento e generosidade. Anuário Antropológico, 43/2, p. 40I-403. 
Silva, Vagner. (2002). Religiões afro-brasileiras. Construção e legitimação de um campo do saber acadêmico (I900I960). Revista USP, 55, p. 82-III.

Silva, Vagner. (2000). O antropólogo e sua magia. São Paulo: Edusp.

Soares, Mariza de Carvalho. (20I4). Trocando galanterias: a diplomacia do comércio de escravos, Brasil-Daomé, I8I0-I8I 2. Afro-Ásia, 49, p. 229-27I.

Soares, Mariza de Carvalho \& Lima, Rachel Corrêa. (2013). A Africana do Museu Nacional; história e museologia. In: Agostini, Camilla (org.). Objetos da escravidão: abordagens sobre a cultura material da escravidão e seu legado. Rio de Janeiro: 7Letras, p. 337-359.

Tamaso, Izabela. (2006). A expansão do patrimônio: novos olhares sobre velhos objetos, outros desafios. Brasília: UnB/ Departamento de Antropologia.

Velho, Gilberto. (2006). Patrimônio, negociação e conflito. Mana. Estudos de Antropologia Social, Rio de Janeiro, I2/I, p. 237-248.

Verger, Pierre. (1992). Os libertos. Sete caminhos na liberdade de escravos da Bahia no século XIX. São Paulo: Corrupio.

Verger, Pierre. (I990). Uma rainha africana mãe de santo em São Luís. Revista USP. São Paulo, 6, p I5I-I58.

Verger, Pierre. (1987) [1968]. Fluxo e refluxo do tráfico de escravos entre o Golfo do Benin e a Bahia de Todos os Santos. Tradução Tasso Gadzanis. São Paulo/Brasília: Corrupio/ Ministério da Cultura.

Verger, Pierre. (1986a). As contribuições especiais das mulheres do candomblé no Brasil. In: Culturas Africanas: documentos da reunião de peritos sobre "As sobrevivências das tradições religiosas africanas nas Caraíbas e na América Latina", colóquio realizado em São Luís do Maranhão, de 24 a 28 de junho de I985, p. 272-29o. Unesco. Documento CC86/WS/37. Digital Library.

Verger, Pierre. (I986b). Um estudo sobre as divindades iorubas, fon, banto com os lugares de culto no Brasil e em paralelo os nomes das divindades correspondentes em África e sua localização. In: Culturas Africanas: documentos da reunião de peritos sobre "As sobrevivên- 
cias das tradições religiosas africanas nas Caraíbas e na América Latina", colóquio realizado em São Luís do Maranhão, de 24 a 28 de junho de I985, p. 29I-308. Unesco. Documento CC86/WS/37. Digital Library.

Verger, Pierre. (1978). Teria o culto dos voduns do Abomey chegado a São Luís do Maranhão pela mãe do rei Ghezo? Revista Maranhense da Cultura, São Luís, 2/2, p. 56-6o.

Verger, Pierre. (I953a). Le culte des voduns d'Abomey aurait-il été apporté à Saint Louis de Maranhon par la mère du roi Ghèzo?. In: Les Afro-américains. Dacar: Institut Français de l'Afrique Noire, p. I57-I60.

Verger, Pierre. (1953b). Influences du Brésil au Golfe du Bénin. In: Les Afro-américains. Dacar: Institut Français de l'Afrique Noire, p. II-IO3.

Unesco. (I986). Culturas Africanas: documentos da reunião de peritos sobre "As sobrevivências das tradições religiosas africanas nas Caraíbas e na América Latina”. Documento CC86/WS/37. Digital Library. 264p. 
Palavras-chave

Casa das Minas;

Sergio Ferretti;

mito e história;

narrativas de origem;

São Luís do Maranhão.
Keywords

Casa das Minas;

Sergio Ferretti;

myth and history;

origin narratives;

São Luís do Maranhão.

\section{A CASA DAS MINAS DE SÃO LUÍS DO MARANHÃO E A SAGA DE NÃ AGONTIMÉ}

\section{Resumo}

A Casa das Minas de São Luís é considerada o mais antigo centro religioso de procedência africana de que se tem notícia no Maranhão. Fundado provavelmente nas primeiras décadas do século XIX, serviu de modelo para outros centros no Norte do Brasil. Tomando por referência os trabalhos de Sergio Ferretti, o artigo apresenta as pesquisas dos anos I940 que estabeleceram a singularidade da origem daomeana da Casa das Minas e examina as diferentes narrativas, em especial aquela formulada por Pierre Verger em I953, que buscaram dar conta de sua fundação. Denominei saga de Nã Agontimé esse conjunto de narrativas que contextualizo, então, com base em trabalhos mais recentes sobre o tráfico negreiro atlântico. $\mathrm{O}$ artigo argumenta que tais narrativas, situadas na confluência entre mito e história, expressam de modo notável a força simbólica da ideia de origem nos estudos socioantropológicos das religiões afro-brasileiras.

\section{THE CASA DAS MINAS OF SÃO LUÍS DO MARANHÃO AND THE SAGA OF NÃ AGONTIMÉ}

\section{Abstract}

The Casa das Minas of São Luís do Maranhão is considered the oldest religious centre of African origin that is known in Maranhão. Probably founded in the first decades of the nineteenth century, it served as a model for other centres in northern Brazil. Setting out from Sérgio Ferretti's writings on the Casa das Minas, the paper presents the research findings that established the singularity of its Dahomean origin in the I940s and examines the different narratives, especially the one formulated by Pierre Verger in I953, which sought to establish its foundation and which I refer to as the saga of Nã Agontimé. More recent works on the Atlantic slave trade allow us to contextualize such narratives more clearly, situating them at the confluence between myth and history, revealing how they express in remarkable fashion the symbolic force of the idea of origin in the socioanthropological studies of Afro-Brazilian religions. 